\title{
$\begin{array}{ll}\text { Research Square } & \text { Preprints are preliminary reports that have not undergone peer review. } \\ \text { They should not be considered conclusive, used to inform clinical practice, } \\ \text { or referenced by the media as validated information. }\end{array}$
}

\section{Elimination of Oxidative Stress and Genotoxicity of Biosynthesized Titanium Dioxide Nanoparticles in Rats via Supplementation with Whey Protein-Coated Thyme Essential Oil}

Mosaad Attia Abdel-Wahhab ( $\nabla$ mosaad_abdelwahhab@yahoo.com )

National Research Center https://orcid.org/0000-0002-7174-3341

Aziza A. El-Nekeety

National Research Centre

Hagar E Mohammed

Sinai University - El Arish Campus

Ola I. Elshafey

National Research Centre

Sekena H. Abdel-Aziem

National Research Centre

Nabila S. Hassan

National Research Centre

\section{Research Article}

Keywords: Titanium dioxide nanoparticles, encapsulation, thyme essential oil, oxidative stress, genotoxicity, food application

Posted Date: April 19th, 2021

DOI: https://doi.org/10.21203/rs.3.rs-398050/v1

License: (c) (i) This work is licensed under a Creative Commons Attribution 4.0 International License. Read Full License 


\section{Abstract}

The green synthesis of metal nanoparticles is growing dramatically; however, the toxicity of these biosynthesized particles against living organisms is not fully explored. Therefore, this study was designed to synthesize and characterize $\mathrm{TiO}_{2}-\mathrm{NPs}$, encapsulation and characterization thyme essential oil (ETEO), determination of the bioactive constituents of ETEO using GC-MS and evaluate their protective role against $\mathrm{TiO}_{2}-\mathrm{NPs}^{-i n d u c e d}$ the oxidative damage and genotoxicity in rats. Six groups of rats were treated orally for 30 days including the control group, $\mathrm{TiO}_{2}-\mathrm{NPs}_{(300}$ $\mathrm{mg} / \mathrm{kg}$ b.w)-treated group, ETEO at low (50 mg/kg b.w) or high dose (100 mg/kg b.w)-treated groups $\mathrm{TiO}_{2}-\mathrm{NPs}$ plus ETEO at the two doses-treated groups. Blood and tissues were collected for different assays. The GC-MS results indicated the presence of 21 compounds belongs to phenols, terpene derivatives, and heterocyclic compounds. The synthesized $\mathrm{TiO}_{2}$-NPs were $45 \mathrm{~nm}$ tetragonal particles with a zeta potential of $-27.34 \mathrm{mV}$; however, ETEO were 119 $\mathrm{nm}$ round particles with a zeta potential of $-28.33 \mathrm{mV}$. $\mathrm{TiO}_{2}-\mathrm{NPs}$ administration disturbs the liver and kidney markers, lipid profile, cytokines, oxidative stress parameters, the apoptotic and antioxidant hepatic mRNA expression and induced histological alterations in the liver and kidney tissues. ETEO could improve all these parameters in a dosedependent manner. It could be concluded that ETEO is a promising candidate for the protection against $\mathrm{TiO}_{2}-\mathrm{NPs}$ and can be applied safely in food applications.

\section{Introduction}

Recently, nanotechnology has developed rapidly in different sectors to improve human life leading to the production of several nanomaterials which developed and extensively used in various fields including industry, food, medicine (Li et al. 2018; Sycheva et al. 2011; Wang et al. 2016; Zahin et al. 2020), personal health care (Sanders et al. 2012; Khosravi et al. 2012) toothpastes (Li et al. 2012), food packaging (Jovanović and Palić 2012; Philbrook et al. 2011) and antimicrobial agents (Martínez-Gutierrez et al. 2012). Titanium dioxide NPs $\left(\mathrm{TiO}_{2}-\mathrm{NPs}\right.$ ) are the most common manufactured worldwide (Jomini et al. 2015). Inhalation of $\mathrm{TiO}_{2}-\mathrm{NPs}$ in mice leads to accumulate these NPs in the hepatic and cardiac tissue and transfer to the circulation after $24 \mathrm{~h}$ (Husain et al. 2015). After oral administration, $\mathrm{TiO}_{2}$-NPs accumulate in different organs mainly the liver, heart, brain and lung inducing damage and inflammation to these organs (Geraets et al. 2014; Kandeil et al. 2020). Additionally, the abdominal injection of mice with $\mathrm{TiO}_{2}-\mathrm{NPs}$ accumulates these particles in different organs and induces severe damage to the liver, heart and kidneys and affects the serum lipids and sugar (Liu et al. 2009). $\mathrm{TiO}_{2}-\mathrm{NPs}$ activate the inflammatory processes and complement cascade in the heart and innate the immune responses mediated by the complement factor 3 in the blood. However, in the liver, these particles alter the gene expression especially that related to the acute phase response (Husain et al. 2015).

Essential Oils (EOs) are the secondary metabolites extracted from different aromatic plants and are categorized as generally recognized as safe (GRAS) by the FDA (Hyldgaard et al. 2012). Thyme (Thymus vulgaris $\mathrm{L}$ ) is a medicinal aromatic plant (Lamiaceae family) has been widely used in food, medicine and agriculture (Morales 2002; Tao et al. 2014). Thyme essential oil (TEO) showed a variety of beneficial biological activities which include antioxidant, antitumor, antimicrobial and anti-inflammatory properties (Nikoli et al. 2014). However, the application of EOs in the food sector is faced by some challenges such as the interaction with different food matrix including proteins, starch and fats (Hyldgaard et al. 2012), their strong volatile characteristic (Khalili et al. 2015). Besides, EOs may alter the sensory characteristics of the foods when used in high concentration, their poor solubility in the aqueous phase (Tao et al. 2014; Barbosa-Cánovas et al. 2009), their sensitivity to light, heat and oxygen during food processing, storage and utilization (Woranuch and Yoksan 2013). To overcome these problems, encapsulation process of EOs may be suitable to solve the challenges face the applications of EOs by enhancing solubility and bioavailability, protection 
against thermal and chemical degradation and control the delivery release at the desired site and time (Tao et al. 2014). The current study was designed to synthesize and characterize $\mathrm{TiO}_{2}$-NPs by green chemistry using orange peel extract, encapsulate and characterize TEO, and evaluate the potential protective activity of the encapsulated TEO (ETEO) against the oxidative damage and genotoxicity of $\mathrm{TiO}_{2}$-NPs in rats.

\section{Materials And Methods Chemicals and Kits}

Titanium tetra isopropoxide (TTIP) and whey protein isolate (WPI) were purchased from Sigma-Aldrich (St. Louis, MO, USA). Kits for transaminase (ALT and AST) were purchased from Randox Co, (Antrim, UK), triglycerides (TriG), cholesterol (Cho), low and high density lipoprotein (LDL, HDL), creatinine, urea, albumin (Alb) and total protein (TP) were purchased from FAR Diagnostics Co. (Via Fermi, Italy). Kits for nitric oxide (NO), glutathione peroxidase (GPx), superoxide dismutase (SOD) and catalase (CAT) were obtained from Eagle diagnostics (Dallas, TX, USA). Malondialdehyde (MDA) kit was purchased from Oxis Research TM Co. (USA). ELISA kit for alpha feta protein (AFP) was purchased from Biochemlmmuno Systems Co. (Montreal, Canada). Tumor necrosis factor-alpha (TNF-a) kit was purchased from Orgenium (Helsinki, Finland). A Kit for measuring carcinoembryonic antigen (CEA) was obtained from Biodiagnostic (Giza, Egypt). PreMixc DNA Kit was obtained from iNtRON Biotechnology (Korea).TRIZOL reagent was purchased from Life Technologies Corporation (Grand Island, NY, USA).

\section{Preparation of $\mathrm{TiO}_{2}-\mathrm{NPs}$}

Fifty gram of the peel of orange was extracted for $2 \mathrm{~h}$ using $150 \mathrm{ml}$ of deionised water at $90{ }^{\circ} \mathrm{C}$. The extract was filtered and was used for the biosynthesis of $\mathrm{TiO}_{2}$-NPs (Balashanmugam et al. 2013). TTIP (1.5 N) was dissolved in distilled water $(100 \mathrm{ml})$ and the extract was added dropwise with constant stirring and pH was maintained to 7 by continuous washing. The mixture was stirred continuously for $6 \mathrm{~h}$ in the light at room temperature. $\mathrm{TiO}_{2}-\mathrm{NPs}_{\mathrm{S}}$ were synthesized, separated using Whatman filter paper, and washed with distilled water several times to remove any byproducts. The obtained wet nanoparticles were dried at $80{ }^{\circ} \mathrm{C}$ overnight and were calcined at $600{ }^{\circ} \mathrm{C}$ for $4 \mathrm{~h}$ (Rao et al. 2015).

\section{Extraction of TEO}

One hundred $\mathrm{g}$ of the plant materials (flowering tops and stalks) were placed in 1 liter of water in a round-bottomed flask which connected with Clevenger-type apparatus and the hydro-distillation was performed for $4 \mathrm{~h}$ by boiling of water. The resulted essential oil was dried over anhydrous sodium sulfate and stored at $4{ }^{\circ} \mathrm{C}$ until used.

\section{GC-MS analysis of TEO}

GC-MS analysis was conducted using Hewlett-Packard model 5890 with a flame ionization detector (FID) and DB-5 fused silica capillary column $(60 \mathrm{~m} \times 0.32 \mathrm{~mm})$. The temperature of the oven was maintained initially at $50^{\circ} \mathrm{C}$ for 5 min and then programmed from 50 to $250^{\circ} \mathrm{C}$ at a rate of $4^{\circ} \mathrm{C} / \mathrm{min}$. The carrier gas was helium at a flow rate of 1.1 $\mathrm{ml} / \mathrm{min}$. The temperatures of the detector and injector were 250 and $220^{\circ} \mathrm{C}$, respectively, and the retention indices (Kovats index) of the separated volatile components were calculated using hydrocarbons as references (C7-C20, Aldrich Co.) as shown by Admas (2007).

\section{Preparation of encapsulated thyme essential oil (ETEO)}


Whey protein isolate (WPI) was dissolved in distilled water with stirring for $1 \mathrm{~h}$. The solution was kept overnight at room temperature before emulsification. Tween 80 was added to the polymer as an emulsifier. Then, the essential oil was progressively added to the polymer solution with homogenization at $20000 \mathrm{rpm}$ for 10 min to form an emulsion. The polymer concentration was $20 \%$, and the amount of essential oil used was $10 \%$ of the mass of the polymer concentration (Jinapong et al. 2008). The emulsion solution was encapsulated by spray drying.

\section{Characterization of $\mathrm{TiO}_{2}-\mathrm{NPs}$ and ETEO}

Scanning electron micrographs (SEM) for $\mathrm{TiO}_{2} \mathrm{NPs}$ were recorded on JEOL JAX-840A and JEOL JEM- 1230 electron micro-analyzers, respectively. However, for ETEO, the droplets were placed onto a carbon-coated copper grid to form a thin liquid film and were negatively stained by one drop of uranyl acetate. The excess staining was removed using filter paper then the film was air-dried before the observation (Pecarski et al., 2014). The image acquisition was done using Orius 1000 CCD camera (GATAN, Warrendale, PA, USA). For measuring zeta potential, the sample of $\mathrm{TiO}_{2}-\mathrm{NPs}$ or ETEO was sonicated for 30-60 min just before assessment. The average diameter The average diameter was calculated using zpw 388 version 2.14 nicomp software. The size distribution and the zeta potential of $\mathrm{TiO}_{2}-\mathrm{NPs}^{2}$ and ETEO were measured using a particle size analyzer (Nano-ZS, Malvern Instruments Ltd., UK).

\section{Animals and experimental design}

Sixty sexually mature male Sprague-Dawley rats (3 months old, 150-160 g) were supplied by the Animal House Lab, National Research Center (NRC), Dokki, Cairo, Egypt. The rats were housed in stainless steel cages in an artificially illuminated (12 $\mathrm{h}$ dark/light cycle) and thermally controlled $\left(25 \pm 1^{\circ} \mathrm{C}\right)$ room free from any source of chemical contamination at the Animal House Lab, NRC, Dokki, Cairo, Egypt. All animals were fed normal chow (Meladco Feed Co., Cairo, Egypt) and housed in filter top polycarbonate cages. The animals were received humane care in compliance with the guidelines of the Animal Care and Use Committee of NRC, and the National Institute of Health (NIH publication 86 - 23 revised 1985). After an acclimatization period of one week, the rats were divided into 6 groups (10 rats/group) and were treated orally using stomach tube for 30 days as follows: group 1; normal control received distilled water, group 2; rats treated with $\mathrm{TiO}_{2}-\mathrm{NPs}(300 \mathrm{mg} / \mathrm{kg} \mathrm{b.w})$ in an aqueous solution, group 3; rats treated with low dose (LD) of ETEO (50 mg/kg b.w), group 4; rats treated with high dose (HD) of ETEO (100 mg/kg b.w), groups 5 and 6; rats treated with LD or HD of ETEO plus $\mathrm{TiO}_{2}-\mathrm{NPs}$. Body weight was recorded each other day and at the end of the treatment period (i.e. day 31), all animals have fasted for $12 \mathrm{hr}$, weighed then blood samples were collected via the retro-orbital venous plexus under isoflurane anesthesia. Sera were centrifuged using cooling centrifuge and kept at $-20{ }^{\circ} \mathrm{C}$ until used for the determination of ALT, AST, lipid profile creatinine, urea, total protein, albumin, AFP, TNF-a and CEA according to the kits instructions. Immediately after blood samples were collected, all animals were euthanized and samples of hepatic and renal tissue from each animal were dissected. A sample of liver and kidney was weighed and homogenized in phosphate buffer $(\mathrm{pH} 7.4)$, centrifuged at $1700 \mathrm{rpm}$ and $4{ }^{\circ} \mathrm{C}$ for 10 min, and the supernatant was separated and used for the estimation of MDA, NO, CAT, GPx, and SOD (Lin et al., 1998). Other samples of these organs from each animal were used for the histological examination. The tissue samples were fixed in $10 \%$ neutral formalin and paraffin-embedded. Sections ( $5 \mu \mathrm{m}$ thickness) were stained with hematoxylin and eosin (H \& E) for the histological examination (Bancroft et al., 1996). However, another sample of liver of each animal was quickly frozen using liquid nitrogen and kept at $-80{ }^{\circ} \mathrm{C}$ for the determination of gene expression.

\section{Gene expression analysis}

RNA was isolated from the liver samples using Trizol reagent. The concentration and the quality of RNA were determined by NanoDrop ${ }^{\text {TM }} 1000$ Spectrophotometer (Thermo Fisher Scientific, USA), and only samples of high 
quality, with A260/A280 ratios between 1.8 and 2.2 were used. Reverse transcription- cDNA synthesis was carried out using a PreMix cDNA Kit (iNtRON Biotechnology, Korea). The obtained cDNA was kept at $-20^{\circ} \mathrm{C}$ for later use or directly used as a semi-quantitative PCR (Sq-PCR) template. The expression of the selected genes was quantified using quantitative real-time PCR (RT-qPCR) performed in a One-Step SYBR Select Master Mix Kit as previously described (Kim et al. 2009). The gene-specific primer sequences for GAPDH, GPx, SOD, CAT, Bax, Bcl-2, and TNF-a are shown in Table (1). RT-qPCR was carried out on Stratagene Mx3005P RT-PCR System (Agilent Technologies) in a 20$\mu \mathrm{L}$ reaction volume using, $1 \mu \mathrm{LcDNA}, 10 \mu \mathrm{M}$ of forward and reverse primers, $10 \mu \mathrm{L}$ TOP real ${ }^{\mathrm{TM}}$ qPCR $2 \times$ PreMIX (SYBR Green with low ROX) (Enzynomics) and DNAse-free water. All samples were amplified in triplicates and the amplification was conducted with a 15 -min denaturation at $95^{\circ} \mathrm{C}$, then 40 cycles of $95^{\circ} \mathrm{C}$ for $12 \mathrm{~s}, 56-63^{\circ} \mathrm{C}$ for $15 \mathrm{~s}$, and $72^{\circ} \mathrm{C}$ for $30 \mathrm{~s}$.

The PCR cycle number $\left(\mathrm{C}_{\mathrm{T}}\right)$ was used for the calculation of expression level where the increased fluorescence curve passes across a threshold value. However, the relative expression of the target genes was obtained using the comparative $\mathrm{C}_{\mathrm{T}}\left(\Delta \Delta \mathrm{C}_{\mathrm{T}}\right)$ method. The $\Delta \mathrm{C}_{\mathrm{T}}$ was calculated by subtracting $\beta$-actin $\mathrm{C}_{\mathrm{T}}$ from that of the target gene; whereas, $\Delta \Delta \mathrm{C}_{\mathrm{T}}$ was obtained by subtracting the $\Delta \mathrm{C}_{\mathrm{T}}$ of the calibrator from that of the test sample. The relative expression was calculated from the $2^{-\triangle \Delta C T}$ formula based on the method of Pfaffl (2001) and Abdel-Wahhab et al. (2021).

\section{Statistical analysis}

Statistical analyses were carried using SPSS 16. Data were expressed as mean \pm SE. Variables were compared using one-way ANOVA; post hoc Duncan's test and the significance of differences among means were determined at $p \leq$ 0.05 .

\section{Results}

The GC-MS analysis of ETEO identified 21 compounds that represent $130.85 \mathrm{mg} / \mathrm{g}$ ETEO and belong to different classes including phenols, terpene, terpene derivatives, and heterocyclic compounds (Table 2). The major compounds were thymol, para-cymene, linalool, carvacrol, camphor, eucalyptol, $\gamma$-terpinene, borneol, terpinene-4-ol, $\beta$ - pinene, $\beta$ Phellandrene, $\beta$-myrcene and Humuline in concentrations of 55.40, 12.1, 8.21, 7.18, 6.21, 6.11, 5.31, 5.12, 4.22, 2.31, $2.14,2.11$ and $2.10 \mathrm{mg} / \mathrm{g}$ ETEO, respectively. Besides, 8 compounds were found in concentrations less than $2 \mathrm{mg} / \mathrm{g}$.

The present results showed that addition of the extract of orange peel to TTIP and stirring in light for $6 \mathrm{~h}$ at the room temperature and $\mathrm{pH} 7$ resulted in the synthesizing of the tetragonal structure of $\mathrm{TiO}_{2}$-NPs (Fig.1a) with an average size of $45 \mathrm{~nm}$ (Fig. 1b) and a zeta potential of $-27.34 \mathrm{mV}$ (Fig. 1c). Moreover, the SEM analysis of ETEO showed a round shape (Fig. 1D) with an average particle size of $110 \mathrm{~nm}$ (Fig. 1E) and a zeta potential of -28.33 mV (Fig. 1F).

The in vivo results revealed that $\mathrm{TiO}_{2}$-NPs significantly decreased the body weight of rats; however; ETEO did not

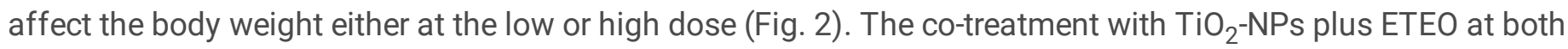
tested doses improved the body weight and no significant difference was observed between the two tested doses. The biochemical indices (Table 3) showed that all the tested parameters were significantly elevated in the group treated with $\mathrm{TiO}_{2}$-NPs except TP and Alb which were decreased significantly. ALT, AST and creatinine were decreased significantly in the animals received ETEO (LD), but no significant change was observed in Alb, TP, D. BIL, urea, and uric acid. However, administration of ETEO (HD) showed a significant decrease in the liver enzymes (ALT, AST) and kidney (creatinine and uric acid) and did not affect the other parameters. Co-administration with $\mathrm{TiO}_{2}-\mathrm{NPs}$ plus ETEO (LD) or ETEO (HD) improved all the biochemical parameters and ETEO (LD) could normalize Alb, TP, and T. BIL; 
meanwhile, ETEO (HD) could normalize all these parameters except ALT and uric acid which were still higher than the control level.

The current data (Table 4) showed the effect of different treatments on lipid profile. Treatment with $\mathrm{TiO}_{2}-\mathrm{NPs}$ increased the lipid profile parameters except HDL which was decreased significantly. Administration of ETEO (LD) increased HDL without any effect on the other lipid parameters; however, ETEO (HD) increased HDL and LDL with no effect on cholesterol or TriG. All the lipid parameters were improved significantly in the groups that received the combined treatment and the low dose could normalize TriG, HDL, and LDL; besides, the high dose could normalize $\mathrm{HDL}$ and LDL. Additionally, $\mathrm{TiO}_{2}$-NPs induced a significant increase in hepatic and renal $\mathrm{NO}$ and MDA (Table 5). ETEO (LD) or ETEO (HD) decreased both parameters in a dose-dependent fashion. Animals that received $\mathrm{TiO}_{2}-\mathrm{NPs}_{\text {plus }}$ ETEO (LD) or ETEO (HD) showed a significant improvement in these markers in a dose-dependent manner. Additionally, $\mathrm{TiO}_{2}$-NPs decreased the activity of the antioxidant enzymes (CAT, SOD, and GPx) in the hepatic and renal tissue (Table 6). Meanwhile, no significant changes were noticed in these enzymes in rats that received ETEO alone at the two doses although the renal GPx and hepatic SOD were significantly increased in these groups. A significant improvement was observed in the animals received the combined treatment of $\mathrm{TiO}_{2}$-NPs plus ETEO, especially the hepatic GPx which was in the normal range of the control. Furthermore, $\mathrm{TiO}_{2}-\mathrm{NPs}$ administration also increased the serum TNF-a, CEA, and AFP (Table 7). ETEO at the low or the high dose did not affect TNF-a and AFP; however, CEA was decreased significantly than the control group. TNF-a returned to normal in the rats treated with $\mathrm{TiO}_{2}-\mathrm{NPs}_{\mathrm{Plus}}$ ETEO (LD) or (HD); meanwhile, AFP and CEA were improved significantly especially in the group that received ETEO (HD).

A quantitative PCR was carried out to estimate the changes in hepatic mRNA gene expression of pro-apoptotic Bax (Fig. 3A), TNF-a (Fig. 3B), and the antiapoptotic Bcl-2 (Fig. 3C) in different treatment groups. $\mathrm{TiO}_{2}-\mathrm{NPs}^{-}$alone increased significantly the mRNA expression of Bax and TNF-a and decreased Bcl-2 mRNA expression. Moreover, GAPDH (housekeeping glyceraldehyde-3-phosphate dehydrogenase gene) indicated an insignificant difference between the untreated control group and those treated with ETEO at the two tested doses in Bax, TNF-a, and Bcl-2 expressions. However, administration of $\mathrm{TiO}_{2}$-NPs plus ETEO at both tested doses could induce remarkable improvement in the transcript levels of these genes.

The cytogenetic study of antioxidant gene expression showed that $\mathrm{TiO}_{2}$-NPs administration markedly reduced the mRNA expression of GPx (Fig. 4A), SOD (Fig. 4B), and CAT (Fig. 4C) compared to the control group. Treatment with ETEO (LD) or (HD) increased significantly the mRNA of GPx gene expression; however, these treatments didn't affect

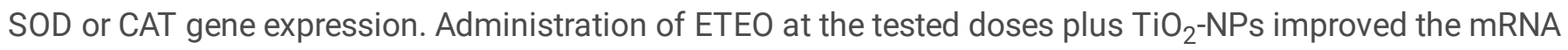
expression of these antioxidant genes towards the control level although these values were still differed significantly from the control group.

The examination of liver sections of the control animals showed the hepatocytes with normal cytoplasm with vesiculated nuclei and separated by blood sinusoids radiating from the central vein (Fig 5A). The liver section of the animals treated with ETEO (LD) showed no observable changes in hepatocytes architecture except few fibrous tissues around the central vein and bile duct hypertrophy (Fig. 5B); however, those treated with ETEO (HD) showed nearly normal hepatocytes architecture (Fig. $5 \mathrm{C}$ ). The examination of liver sections of animals treated with $\mathrm{TiO}_{2}-\mathrm{NPs}$ showed marked histological alterations in hepatocytes as disorganization, vacuolar, and fatty degeneration shrunken hepatocytes with darkly stained pyknotic nuclei, patches of necrotic cells around the dilated and congested portal tract, and numerous mononuclear cellular infiltrations localized in dilated hepatic sinusoids (Fig. 5D). The liver of rats administrated with $\mathrm{TiO}_{2}$-NPs plus ETEO (LD) showed several histological changes in hepatocytes as vacuolar, fatty 
degeneration, pyknotic nuclei and increase in mononuclear inflammatory cells (Fig. 5E). Additionally, the liver of animals in the group that received $\mathrm{TiO}_{2}$-NPs plus ETEO (HD) showed more improvement in hepatic cells stricter but few inflammatory cells were also seen (Fig. 5F).

The examination of kidney cortex sections of the control animals showed the proximal convoluted tubules with high cuboidal acidophilic cells, narrow lumen, and distal convoluted tubules with low cuboidal cells. The renal corpuscle with the parietal layer of Bowman's capsule, glomerulus, and the urinal renal space was preserved (Fig. 6A). The kidney cortex sections of the rats treated with ETEO (LD) showed normal tubules; glomeruli with epithelial cells except some renal tubules showed a slight hyaline droplet in their lumen and widening of the Bowman's space (Fig. 6B). The kidney cortex of the animals treated with ETEO (HD) showed dilatation of tubular lumen with slight cytoplasmic hyaline but the majority of renal tubules, glomeruli, and Bowman's capsule were nearly normal (Fig. 6C). The examination of the renal cortex of animals treated with $\mathrm{TiO}_{2}-\mathrm{NPs}$ showed vacuolar degeneration in the cytoplasm of tubular epithelial cells with deeply stained pyknotic nuclei in some renal tubules. Some of the lining epithelial cells were exfoliated into the lumen with hyaline droplets. The renal capsules were shrunken with a reduction in glomeruli mesangial cells and mononuclear cell infiltrations between degenerated tubule and renal corpuscle (Fig. 6D). The kidney cortex of animals treated with $\mathrm{TiO}_{2}$-NPs plus ETEO (LD) showed few foci of vacuolation in the tubular epithelial cells or hyaline cytoplasmic droplet in their lumen but the majority of renal tubules and glomeruli were nearly normal (Fig. 6E). However, the renal cortex of the animals treated with $\mathrm{TiO}_{2}-\mathrm{NPs}$ plus ETEO (HD) showed few foci of vacuolation in the tubular epithelial cells or cytoplasmic droplet in their lumen with interstitial tubular mononuclear cell infiltrations but the majority of renal tubules and glomeruli were nearly normal (Fig. 6F).

\section{Discussion}

$\mathrm{TiO}_{2}$-NPs are widely utilized in several applications such as sauces, cheeses, ice cream, skimmed milk, food colorants, nutritional supplements, and confectionery products including chewing gum, candy, coating sweets, chocolate, and toothpaste (Bachler et al. 2015; Baranowska-Wójcik et al. 2020; Dudefoi et al. 2017; Peters et al. 2014). Weir et al. (2012) reported that chewing gums, sweets and candies contain high amounts of $\mathrm{TiO}_{2}-\mathrm{NPs}(<100$ $\mathrm{nm}$ ). The absorption of $\mathrm{TiO}_{2}$-NPs via the gastrointestinal tract leads to several organ toxicities including the liver, kidney, serum, testes, and seminal vesicle (Bu et al. 2010; Wang et al. 2007).

In the current work, the results of GC-MS analysis of ETEO revealed the presence of 21 bioactive compounds belongs to phenols, terpene, and terpene derivatives. The phenolic compounds (thymol and carvacrol) represent $62.58 \mathrm{mg} / \mathrm{g}$; however, the terpene and its derivatives represented $65.03 \mathrm{mg} / \mathrm{g}$. These results were in good harmony with those reported in the literature (Amiri 2012; He et al. 2020; Nieto 2020; Youdim et al. 2002). However, the number and concentration of the compounds were somewhat different which probably due to the difference in variety and the growing condition of the plant (Diniz do Nascimento et al. 2010; Mutlu-Ingok et al. 2020; El-Guendouz et al. 2019). The results also showed that the use of orange peel extract as a green approach succeeded to synthesize $\mathrm{TiO}_{2}-\mathrm{NPs}_{\mathrm{s}}$ crystal shape with an average particle size was $45 \mathrm{~nm}$ and a zeta potential of $-27.34 \mathrm{mV}$. Similar to these results, previous reports indicated that crystalline $\mathrm{TiO}_{2}$-NPs were synthesized in different size using the orange peel extract and the size of these synthesized particles was smaller than those synthesized using chemical methods (Rao et al. 2015; Mobeen Amanulla and Sundaram 2019; Thakur et al. 2019). These authors suggested that the syntheses of $\mathrm{TiO}_{2}$-NPs using the orange peel extract was due to its high content of insoluble polysaccharides, soluble sugars and polyphenols which act as reducing agents in addition to the amino acids, citric acid and the carboxylic groups which act as stabilizing agents (Torrado et al. 2011). In a previous work, Patra and Baek (2014) reported that the extract 
concentration, reaction temperature, and $\mathrm{pH}$ are the main factors that affect the particles size and the irregular shape of the synthesized $\mathrm{TiO}_{2}$-NPs may be due to the adhesion of phytochemicals in orange peel extract to particles (Swathi et al. 2019).

The synthesized ETEO reported in this current study showed a round shape with an average size of $110 \mathrm{~nm}$ and a zeta potential of $-28.33 \mathrm{mV}$. These results suggested that WPI, which was used as a wall material in the encapsulation process, enhanced the coalescence of droplets (Abdel-Wahhab et al. 2018). Moreover, the spherical shape of the particles indicated the presence of WPI in the wall of capsules (Eratte et al. 2014; Xu et al. 2013), and the negative zeta potential is also attributed to the negatively charged WPI in neutral pH which is mostly due to the carboxylate groups as the only charged functionalities present in WPI molecule (Eratte et al. 2014). Generally, the surface properties and the particles size have a critical role in nanoparticles uptake by the mucus membranes and the size of 50-300 nm is the preferred size for uptake (Roger et al. 2010) and affect the pharmacokinetics, tissue distribution and clearance of nanoparticles (Sadat et al. 2016). Furthermore, the negative charge of zeta potential can enhance the dispersion of the droplets and increase the stability of the emulsion (McClements and Rao 2011), and the zeta potential higher than $30 \mathrm{mV}$ and lower than - $30 \mathrm{mV}$ stimulate the high stability and prohibit the aggregation of the particles (Mohanraj and Chen 2006).

In the in vivo study, animals were treated with $\mathrm{TiO}_{2}-\mathrm{NPs}$ alone or in combination with ETEO at a low or high dose. The selected dose of $\mathrm{TiO}_{2}$-NPs was based on Orazizadeh et al. (2014); however, the selected dose of ETEO was based on our previous work (El-Nekeety et al. 2011). The toxicity of $\mathrm{TiO}_{2}-\mathrm{NPs}$ was manifested primarily by the effect of body weight. Animals treated with $\mathrm{TiO}_{2}$-NPs alone showed a significant decrease in their final body weight than the control group; meanwhile, no significant change was noticed in body weight of the animals treated with ETEO at both tested doses. It was reported that ingestion of NPs induces disturbances in the digestion and the absorption of food components leading to a shortage of micro and macro elements in the body which in turn affect body weight (McClements et al. 2016). A similar decrease in body weight was reported in mice treated with different doses of $\mathrm{TiO}_{2}$-NPs at different time intervals. The mice showed toxic symptoms including loss of appetite which leads to a reduction in body weight (Chen et al. 2009). Administration of $\mathrm{TiO}_{2}-\mathrm{NPs}$ also reduces the number of villi in the intestine and reduces the surface responsible for nutrients absorption leading to malnutrition and the reduction of body weight (Duan et al. 2010). Furthermore, oral ingestion of $\mathrm{TiO}_{2}-\mathrm{NPs}$ can penetrate the intestinal mucosa (Ammendollia et al. 2017) leading to the damage and chronic failure of the epithelium tissue in the intestinal wall (Brun et al. 2014).

$\mathrm{TiO}_{2}$-NPs administration disturbed the biochemistry of the body as manifested by the significant elevation of liver and kidney function indices, serum cytokines (AFP, CEA, and TNF-a), oxidative markers (NO and MDA), cholesterol, TriG, and LDL and the significant reduction of total protein, albumin, HDL and antioxidant enzyme activity. Previous in vitro studies reported that $\mathrm{TiO}_{2}$-NPs cause toxicity, genotoxicity (Kohen and Nyska 2002), and inflammation (Tucci et al. 2013; Wang et al. 2014; Zhao et al. 2013). The increase in liver and kidney indices reported herein indicated that $\mathrm{TiO}_{2}$-NPs disturb the functions of these organs. The elevation of serum AST and ALT indicated the death or injury of hepatocytes (Thapa and Walia 2007). These enzymes are located in the cytoplasm of hepatic cells more than extracellular fluid and their levels elevate in the serum if the hepatocytes damaged (Dambach et al. 2005; Mohammed and Safwat 2020). Additionally, the elevation of urea, uric acid, and creatinine levels indicate the toxicity and dysfunction of the kidney (Ahamed et al. 2010). Thus, the increase of these kidney indices reported in the $\mathrm{TiO}_{2}-\mathrm{NPs}^{-}$ treated group indicated the injury of renal tissue (Abdelhalim and Jarrar 2011; Fartkhooni et al. 2016). 
Administration of $\mathrm{TiO}_{2}$-NPs also disturbs lipid profile markers. The increase in TriG, cholesterol, and LDL indicate that these nanoparticles affect the lipid metabolism through the effect on lipoprotein lipase enzyme (Ani et al. 2008) and/or the removing and transferring of the lipid fractions (Duan et al. 2010). Additionally, the increase of TriG and cholesterol is associated with cardiovascular disease and other metabolic syndromes (Antoni et al. 2018; Reiner 2017). In addition to the disturbance in cholesterol and TriG, the increase of LDL level is critical because it has also had a close association with arteriosclerosis; hence, $\mathrm{TiO}_{2}-\mathrm{NPs}$ can be considered a causative factor for the incidence of cardiovascular disorders (Chen et al. 2020). Hong et al. (2017) and Chen et al. (2015) reported similar results in mice and rats.

Previous reports proposed that oxidative damage is one of the mechanisms of $\mathrm{TiO}_{2}-\mathrm{NPs}$-induced toxicity. These particles provoke the formation of ROS (reactive oxygen species) in different cell lines (Foroozandeh and Aziz 2015; Wang et al. 2014). In mammals, ROS induces damage to macromolecules such as proteins, lipids, carbohydrates, and nucleic acids mainly DNA (Abdel-Wahhab et al. 20220; Kelly et al. 1998; Shukla et al. 2014; Saquib et al. 2012). Lipid peroxidation (LP) probably changes the cell membrane structure resulting in disturbances in the vital functions of cells (Rikans and Hornbrook 1997). The oxidative damage induced by $\mathrm{TiO}_{2}-\mathrm{NPs}$ is attributed mainly to the generation of hydroxyl radical $(\cdot \mathrm{OH})$ (Reeves et al. 2008). Oral exposure to $\mathrm{TiO}_{2}-\mathrm{NPs}$, lead to the generation of $\cdot \mathrm{OH}$ a status of oxidative stress that occurs leading to the disturbances in lipids and accumulation of malondialdehyde levels and reduction of antioxidant capability in the hepatic tissue (Rajapakse et al. 2012). Also, exposure to $\mathrm{TiO}_{2}-\mathrm{NPs}$ was reported to decrease glutathione in the liver (Federici et al. 2007). The elevation of NO and MDA and the reduction of CAT, GPx, and SOD in the hepatic and renal tissue reported herein suggested the manifestation of oxidative damage and suggesting the disturbances in redox balance in these organs (Chen et al. 2020). The increase of ROS production reflexes the damage of DNA and the up-regulation of 8-hydroxyl deoxyguanosine (8-OHdG) in the hepatic and renal tissue (Trouiller et al. 2009) and the increase of MDA and the decrease of antioxidant enzymes in these organs may contribute to the cell apoptosis. The increase of ROS was reported to increase Nrf2 which consider the master regulator of the expression of several antioxidant genes and the lack of Nrf2 increase the damage of DNA and increases the risk of cancer (Shi et al. 2015). Moreover, hydrogen peroxide $\left(\mathrm{H}_{2} \mathrm{O}_{2}\right)$ in the liver and kidney is accumulated due to the decrease in SOD activity leading to the inhibition of CAT activity (Latchoumycandane and Mathur 2002). This enzyme converts $\mathrm{H}_{2} \mathrm{O}_{2}$, the harmful byproduct of the normal metabolic process, to $\mathrm{H}_{2} \mathrm{O}$ and $\mathrm{O}_{2}$ and thus prevents the damage of cells and tissues (Sharma et al. 2014).

The increased level of serum cytokines reported in the current study in the animals treated with $\mathrm{TiO}_{2}-\mathrm{NPs}$ revealed the inflammatory response of these nanoparticles. These results supported the generation of ROS in $\mathrm{TiO}_{2}-\mathrm{NPs}_{\text {-treated }}$ rats which leads to the reduction of the cell viability and stimulates the cytotoxicity via an apoptotic process (Müller et al. 2010). Thus, the toxicity of $\mathrm{TiO}_{2}$-NPs probably correlated to the surface chemistry of the particles which affects the inflammatory responses and the release of TNF- $a$ and neutrophil-attracting chemokines (lavicoli et al. 2011; Müller et al. 2010; Rossi et al. 2010) and the rate of release is the size and time-dependent (Wu and Tang 2018).

Gene expression assay is widely used as a quick and early biomarker to predict for $\mathrm{TiO}_{2} \mathrm{NPs}_{\text {-induced potential liver }}$ injury and exploring the possible mechanisms of their toxicities ( $\mathrm{Li}$ et al. 2017). The administration of $\mathrm{TiO}_{2}-\mathrm{NPS}$ induced significant disturbances in the expression of antioxidant and apoptosis genes in hepatic tissue. The downregulation of CAT, GPx and SOD mRNA reported herein is harmonized with the biochemical findings and supported the hypothesis that $\mathrm{TiO}_{2}$-NPs induce oxidative stress via the exhaustion of antioxidant enzymes and suppress their gene expression. Moreover, $\mathrm{TiO}_{2}$-NPs also decreased $\mathrm{Bcl}-2$ mRNA expression and up-regulation of Bax and TNF-a mRNA in the liver. Bcl-2 proteins are family responsible for anti-apoptosis and control the mitochondrial integrity 
surface, while Bax is a pro-apoptotic protein. The balance of anti-apoptotic Bcl-2 and the pro-apoptotic Bax proteins control the sensitivity of the cell to apoptotic stimuli (Ilani et al. 2018). Additionally, Bcl-2 is found on the surface of mitochondria and prevents the release of cytochrome $c$ in the plasma; however, Bax encourages the leakage of cytochrome $c$ through the punching of the holes of the mitochondrial membrane (Kroemer et al. 2007). The imbalance between Bax and Bcl-2 also activates the pathway of caspase-dependent apoptotic (Peng et al. 2016). Thus, the generation of ROS after $\mathrm{TiO}_{2}$-NPs exposure disturbs the mitochondrial membrane potential as a result of apoptosis (Abdel-Wahhab et al. 2020; Zhao et al. 2009). Furthermore, the up-regulation of TNF-a mRNA in the hepatic tissue indicated the inflammatory response of $\mathrm{TiO}_{2}$-NPs and supported the earlier findings of the previous studies (Chen et al. 2015; Gui et al. 2011; Trouiller et al. 2009).

The histological examination of the liver and kidney tissues revealed that $\mathrm{TiO}_{2}-\mathrm{NPs}$ administration induced severe pathological changes in both tissues and confirmed the biochemical and cytogenetic results. Similar observations were reported in previous studies (Attia et al. 2013; Morgan et al. 2018) who reported disorganization of the hepatic cords with hepatocellular necrosis, macro, and microvascular steatosis. Moreover, Valentini et al. (2019) reported that the alterations on the liver tissue were mainly correlated with oxidative stress which is localized around the central vein. A close correlation between oxidative damage and anoxia of the tissue was reported in different organs (Chen et al. 2005; Pialoux et al. 2009). Moreover, the hepatic Kuffer cells are well-known to be the most impacted cells by oxidative stress which may be due to their localization around the portal area in the liver sinusoids (Olmedo et al. 2008). On the other hand, the histological changes in the kidney tissues are characterized by the accumulation of protein materials in the lumen of many distal tubules and the collecting ducts found in the medulla which is less oxygenated compared to the proximal tubules and may be more exposed to the oxidative stress generated by $\mathrm{TiO}_{2}{ }^{-}$ NPs (Epstein 1997).

The prophylactic activity of thyme essential oils is well documented in the literature; however, some limitations were reported for its application in the food and pharmaceutical sectors. To cope with these limitations, encapsulation technology was proposed. This technique able to enhance the oil solubility and bioavailability, protect their active components against thermal or chemical degradation and control the release of these components (Tao et al. 2014). The encapsulated thyme essential oil (ETEO) in WPI was applied for the protection against $\mathrm{TiO}_{2}-\mathrm{NPs}_{\text {-induced }}$ oxidative damage and genotoxicity. The antioxidant properties and the protective role of ETEO are focused on the major phenolic components mainly thymol and carvacrol (Ruberto and Baratta 2000). Beside these two major components, the other components in the oil such as linalool, myrcene, and y-terpinene enhance the antioxidant activity of the oil (Youdim et al. 2002). Animals treated with ETEO alone exhibited significant improvements in all biochemical parameters especially, the antioxidant enzyme activity and oxidative markers suggesting that ETEO enhances the antioxidant activity. Previous reports indicated that thyme oil reduces the oxidation rate through the elimination of ROS or the breakdown of the peroxides to stable substances and prevent the promotion of further oxidation (El-Newary 2017). ETEO also improved the body weight, biochemical parameters, cytokines, antioxidant enzymes, and their gene expression in rats treated with $\mathrm{TiO}_{2}-\mathrm{NPs}$. These improvements may be due to the elimination of ROS generation which responsible for protein damage and lipid oxidation of cell membrane as well as the disturbances in calcium homeostasis and increase the fluidity of membrane and the death of cells (Molavian et al. 2016). Furthermore, the high content of phenolic compounds in the oil was found to decrease the triglycerides and cholesterol in the hepatic and renal tissue (Ebenyi et al. 2012). These compounds also prevent the secretion of proinflammatory factors through the reduction of lipopolysaccharides (De Andrade et al. 2017), thus, they are potent ROS scavengers' natural products (Ebenyi et al. 2012) and increase the production of GSH, SOD, and CAT (EI-Banna et al. 2013). It was also reported that thyme oil can suppress TNF-a in mouse cells and inhibited cytochrome $C$ oxidase-2 expression (Mahran et al. 2019). Generally, the protective role of bioactive components in ETEO maybe 
include the inhibition of cytochrome P450 activity, accelerate the regeneration of parenchyma cells, stabilizing the cell membrane, improvement of the antioxidant activity (Al-Fartosi et al. 2011). Previous reports indicated that encapsulation of thyme oil (TO) using different materials improve its properties. In this concern, several studies reported that the antioxidant activity, the thermal stability, and the release of the oil were improved when the oil was encapsulated using zein (Bilenler et al. 2015) chitosan (Detsi et al. 2020; Ghahfarokhi et al. 2016; Khalili et al. 2015), Arabic gum (Cai et al. 2019), gelatin-Arabic gum (Gonçalves et al. 2017) and chitosan-Arabic gum (Hassani and Hasani 2018).

In our study, WPI was used as a wall in the encapsulation process, thus, we can propose another mechanism of the protective role of ETEO. WPI is well known to possess antioxidant activity due to its high content of amino acids mainly cysteine, $\beta$-lactoglobulin, a-lactoglobulin, and bovine serum albumin (Morr and Ha 1993). The amino acid cysteine helps to replenish intracellular GSH, the endogenous antioxidant responsible for peroxide dexification (Gould and Pazdro 2019). Hence it acts as another source of antioxidants besides its role in the protection of the oil active ingredients and enhances the activity of ETEO.

\section{Conclusion}

The current results showed that 21 compounds were identified in TEO represented $130.85 \mathrm{mg} / \mathrm{g}$ oil and belong to phenols, terpene, and terpene derivatives class. Thymol, para-cymene, linalool, carvacrol, camphor, eucalyptol, $\gamma^{-}$ terpinene, borneol, terpinene-4-ol, $\beta$ - pinene, $\beta$-Phellandrene, $\beta$-myrcene and Humuline in concentrations were the major compounds. $\mathrm{TiO}_{2}$-NPs can be synthesized using orange peel extract and the resulted particles were tetragonal with an average size of $45 \mathrm{~nm}$ and zeta potential of $-27.34 \mathrm{mV}$. The results also revealed that the encapsulation of TEEO using WPI resulted in round particles with an average size of $110 \mathrm{~nm}$ and a zeta potential of $-28.33 \mathrm{mV}$. The biological study revealed that $\mathrm{TiO}_{2}$-NPs induced severe toxicity to the hepatic and renal tissues as manifested by the decrease of body weight, disturbed liver and kidney function, lipid profile parameters, increased serum cytokines, NO and $\mathrm{MDA}$. $\mathrm{TiO}_{2}$-NPs also increased the mRNA of pro-apoptotic and decrease the mRNA expression of antiapoptotic and antioxidant enzymes along with the pathological alterations in the liver and kidney tissues. ETEO did not induce any significant changes in all the parameters tested or the histological picture of the liver and kidney. Co-treatment with $\mathrm{TiO}_{2}$-NPs plus ETEO at both tested doses enhanced the antioxidant activity and alleviated the toxicity of $\mathrm{TiO}_{2}-$ NPs in a dose-dependent manner. Encapsulation of TEO in WPI enhanced its antioxidant activity and maybe a promising candidate to protect against $\mathrm{TiO}_{2}$-NPs-induced oxidative stress and genotoxicity. ETEO can be applied to overcome the problems associated with essential oils and used in food or pharmaceutical applications for the protection against oxidative damage.

\section{Declarations}

\section{Funding}

This work was supported by the National Research Centre, Dokki, Cairo, Egypt project \# 12050305.

\section{Availability of data and material}

The datasets generated during and/or analyzed during the current study are available from the corresponding author on reasonable request.

\section{Code availability}

Page $11 / 28$ 
The codes used during the current study are available from the corresponding author on reasonable request.

\section{Compliance with ethical standards}

The authors declare that they have no conflict of interest.

Ethics approval The protocol of the current study was approved by the ethics Animal Care and Use Committee of the National research Center, Dokki, Cairo, Egypt (approval \# 12050305/2019)

Consent for publication Not applicable

Consent to Participate Not applicable

Authors' contributions: This work was carried out in collaboration between all authors. Authors EL-Nekeety, HE Mohammed and OI Elshafey prepared and characterized the nanoparticles, carried out the experimental work, the biochemical analysis and managed the literature search. Author SH Abdel-Aziem carried out the genetic analysis. Author NS. Hassan carried out the histological part. All authors shared in writing the first draft. Author Mosaad A. Abdel-Wahhab wrote the protocol, managed the project, managed the analyses of the study, performed the statistical analysis, and wrote the final draft of the manuscript. All authors read and approved the final manuscript.

\section{References}

1. Abdelhalim MAK, Jarrar BM (2011) The appearance of renal cells cytoplasmic degeneration and nuclear destruction might be an indication of GNPs toxicity. Lipids Health Dis 10:147

2. Abdel-Wahhab MA, El-Nekeety AA, Hassan NS, Gibriel AA, Abdel-Wahhab KG (2018) Encapsulation of cinnamon essential oil in whey protein enhances the protective effect against single or combined sub-chronic toxicity of fumonisin $B_{1}$ and/or aflatoxin $B_{1}$ in rats. Environ Sci Pollu Res 25(29):29144-29161

3. Abdel-Wahhab MA, El-Nekeety AA, Hathout AS, Salman AS, Abdel-Aziem SH, Hassan NS, Abdel-Aziz MS (2020) Secondary metabolites from Bacillus sp. MERNA97 extract attenuate the oxidative stress, genotoxicity and cytotoxicity of aflatoxin $B_{1}$ in rats. Food Chem Toxicol 141: 111399 doi.org/10.1016/j.fct. 2020.111399

4. Abdel-Wahhab MA, Hassan MA, El-Nekeety AA, Abdel-Aziem SH, Hassan NS, Jaswir I, Salleh HM (2021) Zinc citrate loaded whey protein nanoparticles ameliorate $\mathrm{CCl}_{4}$-induced testicular injury via the regulation of Nrf2Keap1 antioxidative signaling pathway. J Drug Deliv Sci Technol 61:102322

5. Adams RB (2007) Identification of essential oil components by gas chromatography/quadruple mass spectroscopy. Allured publishing Co., Carol Stream

6. Ahamed M, AISalhi MS, Siddigui MKJ (2010) Silver nanoparticle applications on human health. Clin Chim Acta 411:1841-1848

7. Al-Fartosi KG, Khuon OS, Al-Tae HI (2011) Protective role of camel's milk against paracetamol induced hepatotoxicity in male rats. Int J Res Pharma Biomed Sci 2:1795-1799

8. Amiri H (2012) Essential oils composition and antioxidant properties of three thymus species. Evid Based Complement Alternat Med 728065. doi:10.1155/2012/728065

9. Ammendolia MG, losi F, Maranghi F, Tassinari R, Cubadda F, Aureli F, Raggi A, Superti F, Mantovani A, Berardis B (2017) Short-term oral exposure to low doses of nano-sized $\mathrm{TiO}_{2}$ and potential modulatory effects on intestinal cells. Food Chem Toxicol 102:63-75

Page $12 / 28$ 
10. Ani A, Ani M, Moshtaghie AA, Ahmadvand H (2008) Changes in liver contents of lipid fractions following titanium exposure. Iranian J Pharm Res 2008: 179-183

11. Antoni R, Johnston KL, Collins AL, Robertson MD (2018) Intermittent v. continuous energy restriction: differential effects on postprandial glucose and lipid metabolism following matched weight loss in overweight/obese participants. Br J Nutr 119(5):507-516

12. Attia H, Soliman G, Abdel Rahman A, Nassan A, Shimaa A (2013) Hepatoprotective effect of N-acetylcysteine on the toxic hazards of titanium dioxide nanoproticles. Am J Pharmacol Toxicol 8:141-147

13. Bachler G, von Goetz N, Hungerbuhler K (2015) Using physiologically based pharmacokinetic (PBPK) modeling for dietary risk assessment of titanium dioxide $\left(\mathrm{TiO}_{2}\right)$ nanoparticles. Nanotoxicol 9:373-380

14. Balashanmugam P, Nandhini R, Vijayapriyadharshini V, Kalaichelvan PT (2013) Biosynthesis of silver nanoparticles from orange peel extract and its antibacterial activity against fruit and vegetable pathogens. Int $\mathrm{J}$ Innovative Res Sci Eng 1(2):6 pages

15. Bancroft D, Stevens A, Turmer R (1996) Theory and practice of histological technique, 4th edn. Churchill Living Stone, Edinburgh, pp 36-42

16. Baranowska-Wójcik E, Szwajgier D, Oleszczuk P, Winiarska-Mieczan A (2020) Effects of titanium dioxide nanoparticles exposure on human health-a review. Biol Trace Elem Res 193:118-129

17. Barbosa-Cánovas G, Mortimer A, Lineback D, Spiess W, Buckle K, Colonna P (2009) Global issues in food science and technology. In: Weiss J, Gaysinsky S, Davidson M, McClements J Nanostructured encapsulation systems: food antimicrobials. Academic Press, New York, pp 425-479 Eds ).

18. Bilenler T, Gokbulut I, Sislioglu K, Karabulut I (2015) Antioxidant and antimicrobial properties of thyme essential oil encapsulated in zein particles. Flavour Fragr J 30:392-398

19. Brun E, Barreau F, Veronesi G, Fayard B, Sorieul S, Chanéac C, Rabilloud T, Mabondzo A, Herlin-Boime N, Carrière M (2014) Titanium dioxide nanoparticle impact and translocation through ex vivo, in vivo and in vitro gut epithelia. Part Fibre Toxicol 11:2-16

20. Bu Q, Yan G, Deng P, Peng F, Lin H, Xu Y, Cao Z, Zhou T, Xue A, Wang Y, Cen X, Zhao Y-L (2010) NMR-based metabonomic study of the sub-acute toxicity of titanium dioxide nanoparticles in rats after oral administration. Nanotechnol 21(12):125105

21. Cai C, Ma R, Duan M, Lu D (2019) Preparation and antimicrobial activity of thyme essential oil microcapsules prepared with gum Arabic. RSC Adv 9:19740-19747

22. Chen J, Dong X, Zhao J, Tang G (2009) In vivo acute toxicity of titanium dioxide nanoparticles to mice after intraperitioneal injection. J Appl Toxicol 29:330-337

23. Chen L, Einbinder E, Zhang Q, Hasday J, Balke CW, Scharf SM (2005) Oxidative stress and left ventricular function with chronic intermittent hypoxia in rats. Am J Respir Crit Care Med 172(7):915-920

24. Chen Z, Han S, Zheng P, Zhou D, Zhou S, Jia G (2020) Effect of oral exposure to titanium dioxide nanoparticles on lipid metabolism in Sprague-Dawley rats. Nanoscale. doi:10.1039/c9nr10947a

25. Chen Z, Wang Y, Zhuo L, Chen S, Zhao L, Luan X, Wang H, Jia G (2015) Effect of titanium dioxide nanoparticles on the cardiovascular system after oral administration. Toxicol Lett 239(2):123-130

26. Chen J, Dong X, Xin Y, Zhao M (2011) Effects of titanium dioxide nano-particles on growth and some histological parameters of zebrafish (Danio rerio) after a long-term exposure. Aquat Toxicol 101:493-499

27. Dambach DM, Andrews BA, Moulin F (2005) New technologies and screening strategies for hepatotoxicity: use of in vitro models. Toxicol Pathol 33(1):17-26

Page 13/28 
28. De Andrade CJ, Andrade LR, Silvana SM, Pastore G, Jauregi P (2017) A novel approach for the production and purification of mannosylerythritol lipids (MEL) by Pseudozyma tsukubaensis using cassava wastewater as substrate. Sep Purif Technol 180:157-167

29. Detsi A, Kavetsou E, Kostopoulou I, Pitterou I, Pontillo ARN, Tzani A, Christodoulou P, Siliachli A, Zoumpoulaki P (2020) Nanosystems for the encapsulation of natural products: The case of chitosan biopolymer as a matrix. Pharmaceutics 12:669. doi:10.3390/pharmaceutics12070669

30. Diniz do Nascimento L, Moraes AAB, Costa KSD, Pereira Galúcio JM, Taube PS, Costa CML, Neves Cruz J, de Aguiar Andrade EH, Faria LJG (2020) Bioactive natural compounds and antioxidant activity of essential oils from spice plants: New findings and potential applications. Biomolecules 10(7): 988 https://doi.org/10.3390/ biom10070988

31. Duan Y, Liu J, Ma L, Li N, Liu H, Wang J, Zheng L, Liu C, Wang X, Zhao X, Yan J, Wang S, Wang H, Zhang X, Hong F (2010) Toxicological characteristics of nanoparticulate anatase titanium dioxide in mice. Biomater 31(5):894899

32. Dudefoi W, Moniz K, Allen-Vercoe E, Ropers MH, Virginia K (2017) Impact of food grade and nano-TiO 2 particles on a human intestinal community. Food Chem Toxicol 106:242-249

33. Ebenyi LN, Ibiam UA, Aja PM (2012) Effects of Allium sativum extract on paracetamol induced hepatotoxicity in albino rats. IRJBB 2:93-97

34. El-Banna H, Solimanand M, Al-Wabel N (2013) Hepatoprotective effects of thymus and salvia essential oils on paracetamol induced toxicity in rats. J Phys Pharm Adv 3:41-47

35. El-Guendouz S, Aazza S, Anahi Dandlen S, Majdoub N, Lyoussi B, Raposo S, Dulce AM, Gomes V, Graça Miguel M (2019) Antioxidant activity of thyme waste extract in o/w emulsions. Antioxidants (Basel) 8(8):243. doi:10.3390/antiox8080243

36. El-Nekeety AA, Mohamed SR, Hathout AS, Hassan NS, Aly AE, Abdel-Wahhab MA (2011) Antioxidant properties of Thymus vulgaris oil against aflatoxin-induce oxidative stress in male rats. Toxicon 57:984-991

37. El-Newary SA, Shaffie NM, Omer EA (2017) The protection of Thymus vulgaris leaves alcoholic extract against hepatotoxicity of alcohol in rats. Asian Pac J Trop Med 10(4):361-371

38. Epstein FH (1997) Oxygen and renal metabolism. Kidney Int 51(2):381-385

39. Eratte D, Wang B, Dowling K, Barrow CJ, Adhikari BP (2014) Complex coacervation with whey protein isolate and gum arabic for the microencapsulation of omega-3 rich tuna oil. Food Funct 5:2743-2750

40. Fartkhooni FM, Noori A, Mohammadi A (2016) Effects of titanium dioxide nanoparticles toxicity on the kidney of male rats. Int J Life Sci 10(1):65-69

41. Federici G, Shaw BJ, Handy RD (2007) Toxicity of titanium dioxide nanoparticles to rainbow trout (Oncorhynchus mykiss): gill injury, oxidative stress, and other physiological effects. Aquat Toxicol 84:415-430

42. Foroozandeh P, Aziz AA (2015) Merging worlds of nanomaterials and biological environment: factors governing protein corona formation on nanoparticles and its biological consequences. Nanoscale Res Lett 10:221. doi:10.1186/s11671-015-0922-3

43. Geraets L, Oomen AG, Krystek P, Jacobsen NR, Wallin H, Laurentie M, Dulce AM, Gomes V, Graça MM (2104) Tissue distribution and elimination after oral and intravenous administration of different titanium dioxide nanoparticles in rats. Part Fibre Toxicol 2014:11

44. Ghaderi-Ghahfarokhi M, Barzegar M, Sahari MA, Aziz MH (2016) Nanoencapsulation approach to improve antimicrobial and antioxidant activity of thyme essential oil in beef burgers during refrigerated storage. Food Bioproc Technol 9:1187-1201

Page $14 / 28$ 
45. Gonçalves ND, Pena FD, Sartoratto A, Derlamelina C, Duarte MCT, Antunes AEC, Prata AS (2017) Encapsulated thyme (Thymus vulgaris) essential oil used as a natural preservative in bakery product. Food Res Int 96:154-160

46. Gould RL, Pazdro R (2019) Impact of supplementary amino acids, micronutrients, and overall diet on glutathione homeostasis. Nutrients 11(5):1056. doi:10.3390/nu11051056

47. Gui S, Zhang Z, Zheng L, Cui Y, Liu X, Li N, Sang X, Sun Q, Gao G, Cheng Z, Cheng J, Wang L, Tang M, Hong F (2011) Molecular mechanism of kidney injury of mice caused by exposure to titanium dioxide nanoparticles. J Hazard Mater 195:365-370

48. Hassani M, Hasani S (2018) Nano-encapsulation of thyme essential oil in chitosan-Arabic gum system: evaluation of its antioxidant and antimicrobial properties. Trends Phytochem Res 2(2):75-82

49. He T, Li X, Wang X, Xu X, Yan X, Li X, Sun S, Dong Y, Ren X, Liu X, Wang Y, Sui H, Xia Q, She G (2020) Chemical composition and antioxidant potential on essential oils of Thymus quinquecostatus Celak. from Loess Plateau in China, regulating Nrf2/Keap1 signaling pathway in zebrafish. Sci Rep 10(1):11280

50. Hong F, Zhou Y, Zhao X, Sheng L, Wang L (2017) Maternal exposure to nanosized titanium dioxide suppresses embryonic development in mice. Int J Nanomed 12:6197-6204

51. Husain M, Wu D, Saber AT, Decan N, Jacobsen NR, Williams A, Yauk CL, Wallin H, Vogel U, Halappanavar S (2015) Intratracheally instilled titanium dioxide nanoparticles translocate to heart and liver and activate complement cascade in the heart of C57BL/6 mice. Nanotoxicol 9:1013-1022

52. Hyldgaard M, Mygind T, Meyer RL (2012) Essential oils in food preservation: mode of action, synergies, and interactions with food matrix components. Front Microbiol 3:1-24

53. Iavicoli I, Leso V, Fontana I, Bergamaschi A (2011) Toxicological effects of titanium dioxide nanoparticles: a review of in vitro mammalian studies. Eur Rev Med Pharmacol Sci 15:481-508

54. Ilani M, Alaee S, Khodabandeh Z, Jamhiri I, Owjfard M (2018) Effect of titanium dioxide nanoparticles on the expression of apoptotic markers in mouse blastocysts. Toxicol Environ Chem 100(2):228-234

55. Jinapong N, Suphantharika M, Jammong P (2008) Production of instant soymilk powders by ultrafiltration, spray drying and fluidized bed agglomeration. J Food Eng 84:194-205

56. Jomini S, Clivot $\mathrm{H}$, Bauda P, Pagnout $\mathrm{C}$ (2015) Impact of manufactured $\mathrm{TiO}_{2}$ nanoparticles on planktonic and sessile bacterial communities. Environ Pollut 202: 196-204, 2015

57. Jovanović B, Palić D (2012) Immunotoxicology of non-functionalized engineered nanoparticles in aquatic organisms with special emphasis on fish-review of current knowledge, gap identification, and call for further research. Aquat Toxicol 15(118-119):141-151

58. Kelly KA, Havrilla CM, Brady TC, Abramo KH, Levin ED (1998) Oxidative stress in toxicology: established mammalian and emerging piscine model systems. Environ Health Perspect 106:375-384

59. Khalili ST, Mohsenifar A, Beyki M, Zhaveh S, Rahmani-Cherati T, Abdollahi A, Bayat M, Tabatabaei M (2015) Encapsulation of thyme essential oils in chitosan-benzoic acid nanogel with enhanced antimicrobial activity against Aspergillus flavus. LWT- Food Sci Technol 60(1):502-508

60. Khosravi K, Hoque ME, Dimock B, Hintelmann H, Metcalfe CD (2012) A novel approach for determining total titanium from titanium dioxide nanoparticles suspended in water and biosolids by digestion with ammonium persulfate. Anal Chim Acta 713:86-91

61. Kim HD, Shay T, O'Shea EK, Regev A (2009) Transcriptional regulatory circuits: predicting numbers from alphabets. Science 325(5939):429-432

62. Kohen R, Nyska A (2002) Oxidation of biological systems: oxidative stress phenomena, antioxidants, redox reactions, and methods for their quantification. Toxicol Pathol 30:620-650

Page $15 / 28$ 
63. Kroemer G, Galluzzi L, Brenner C (2007) Mitochondrial membrane permeabilization in cell death. Physiol Rev 87:99-163

64. Latchoumycandane $C$, Mathur P (2002) Induction of oxidative stress in the rat testis after short-term exposure to the organochlorine pesticide methoxychlor. Arch Toxicol 76(12):692-698

65. Li BR, Hu Z, Cheng J, Xie Y, Gui SX, Sun QQ, Sang XZ, Gong XL, Cui YL, Shen WD, Hong FS (2012) Titanium dioxide nanoparticles relieve biochemical dysfunctions of fifth-instar larvae of silkworms following exposure to phoxim insecticide. Chemosphere 89(5):609-614

66. Li Y, Yan J, Ding W, Chen Y, Pack LM, Chen T (2017) Genotoxicity and gene expression analyses of liver and lung tissues of mice treated with titanium dioxide nanoparticles. Mutagenesis 32(1):33-46

67. Li J, Wang XX, Zhao GX, Chen CL, Chai ZF, Alsaedi A, Hayat T, Wang X (2018) Metal-organic framework-based materials: superior adsorbents for the capture of toxic and radioactive metal ions. Chem Soc Rev 47:2322-2356

68. Lin CC, Hsu YF, Lin TC, Hsu FL, Hsu HY (1998) Antioxidant and hepatoprotective activity of Punicalagin and Punicalin on carbon tetrachloride induced liver damage in rats. J Pharm Pharmacol 50(7):789-794

69. Liu H, Ma L, Zhao J, Liu J, Yan J, Ruan J, Hong F (2009) Biochemical toxicity of nano-anatase $\mathrm{TiO}_{2}$ particles in mice. Biol. Trace Elem. Res. 129, 70-80, Erratum in. Biol. Trace Elem Res 129: 170-180

70. Mahran YF, Badr AM, Aldosari A, Bin-Zaid R, Alotaibi HN (2019) Carvacrol and thymol modulate the cross-talk between TNF-a and IGF-1 Signaling in radiotherapy-induced ovarian failure. Oxid Med Cell Longev 2019: 3173745. doi:10.1155/2019/3173745

71. Martínez-Gutierrez F, Thi EP, Silverman JM, de Oliveira CC, Svensson SL, Vanden HA, Sánchez EM, Reiner NE, Gaynor EC, Pryzdial EL, Conway EM, Orrantia E, Ruiz F, Av-Gay Y, Bach H (2012) Antibacterial activity, inflammatory response, coagulation and cytotoxicity effects of silver nanoparticles. Nanomed 8(3):328-336

72. McClements DJ, DeLoid G, Pyrgiotakis G, Shatkin JA, Xiao H, Demokritou P (2016) The role of the food matrix and gastrointestinal tract in the assessment of biological properties of ingested engineered nanomaterials (iENMs): state of the science and knowledge gaps. Nanolmpact 3:47-57

73. McClements DJ, Rao J (2011) Food-grade nanoemulsions: formulation, fabrication, properties, performance, biological fate, and potential toxicity. Crit Rev Food Sci Nutr 51(4):285-330

74. Mobeen Amanulla A, Sundaram R (2019) Green synthesis of $\mathrm{TiO}_{2}$ nanoparticles using orange peel extract for antibacterial, cytotoxicity and humidity sensor applications. Mater Today Proc 8:323-331

75. Mohammed ET, Safwat GM (2020) Grape seed proanthocyanidin extract mitigates titanium dioxide nanoparticle ( $\mathrm{TiO}_{2}$-NPs)-induced hepatotoxicity through TLR-4/NF-kB signaling pathway. Biol Trace Elem Res 196:579-589

76. Mohanraj VJ, Chen Y (2006) Nanoparticles a review. Trop J Pharm Res 5:561-573

77. Molavian HR, Goldman A, Phipps CJ, Kohandel M, Wouters BG, Sengupta S, Sivaloganathan S (2016) Druginduced reactive oxygen species (ROS) rely on cell membrane properties to exert anticancer effects. Sci Rep 6:27439. https://doi.org/10.1038/srep27439

78. Morales R (2002) Medicinal and aromatic plants industrial profiles, In: The History, Botany and Taxonomy of the Genus Thymus. (Eds.): Stahl-Biskup E. Saez F. Taylor Francis, London, PP1-44

79. Morgan A, Ibrahim MA, Galal MK, Ogaly HA, Abd-Elsalam RM (2018) Innovative perception on using Tiron to modulate the hepatotoxicity induced by titanium dioxide nanoparticles in male rats. Biomed Pharmacother 103:553-561

80. Morr CV, Ha EYW (1993) Whey protein concentrates and isolate processing and functional properties. Crit Rev Food Sci Nutr 33:431-476 
81. Müller L, Riediker M, Wick P, Mohr M, Gehr P, Rothen-rutishauser B (2010) Oxidative stress and inflammation response after nanoparticle exposure: differences between human lung cell monocultures and an advanced three-dimensional model of the human epithelial airways. J R Soc Interface 7(Suppl 1):S27-S40

82. Mutlu-Ingok A, Devecioglu D, Dikmetas DN, Karbancioglu-Guler F, Capanoglu E (2020) Antibacterial, antifungal, antimycotoxigenic, and antioxidant activities of essential oils: an updated review. Molecules 25(20):4711 doi.org/10.3390/molecules 25204711

83. Nieto G (2020) A review on applications and uses of thymus in the food industry. Plants (Basel) 9(8):961. doi:10.3390/plants9080961

84. Nikoli M, Jasmina Glamočlija J, Isabel CFR, Ferreira ICFR, Ricardo C, Calhelha RC, Ângela Fernandes A, Tatjana Marković T, Dejan Marković D, Abdulhamed Giweli A, Marina Soković M (2014) Chemical composition, antimicrobial, antioxidant and antitumor activity of Thymus serpyllum L., Thymus algeriensis Boiss. and Thymus vulgaris L. essential oils. Ind Crop Prod 52: 18-190

85. Olmedo DG, Tasat DR, Evelson P, Guglielmotti MB, Cabrini RL (2008) Biological response of tissues with macrophagic activity to titanium dioxide. J Biomed Mater Res Part A 84(4):1087-1093

86. Orazizadeh M, Khorsandi L, Absalan F, Hashemitabar M, Daneshi E (2014) Effect of beta-carotene on titanium oxide nanoparticles induced testicular toxicity in mice. J Assist Reprod Genet 31:561-568

87. Patra JK, Baek KH (2014) Green nanobiotechnology: factors affecting synthesis and characterization techniques. J Nanomater 2014:1-12

88. Pecarski D, Knežević-Jugović Z, Dimitrijević-Branković S, Mihajilovski K, Janković S (2014) Preparation, characterization and antimicrobial activity of chitosan microparticles with thyme essential oil. Hem Ind 68(6):721-729

89. Peng X, Chen K, Chen J, Fang J, Cui H, Zuo Z, Deng J, Chen Z, Geng Y, Lai W (2016) Aflatoxin B 1 affects apoptosis and expression of $\mathrm{Bax}, \mathrm{Bcl}-2$, and Caspase-3 in thymus and bursa of fabricius in broiler chickens. Environ Toxicol 31(9):1113-1120

90. Peters RJ, van Bemmel G, Herrera-Rivera Z, Helsper HP, Marvin HJ, Weigel S, Tromp PC, Oomen AG, Rietveld AG, Bouwmeester $\mathrm{H}$ (2014) Characterization of titanium dioxide nanoparticles in food products: analytical methods to define nanoparticles. J Agric Food Chem 62:6285-6293

91. Pfaffl MW (2001) A new mathematical model for relative quantification in real-time RT-PCR. Nucleic Acids Res 29(900):2002-2008

92. Philbrook NA, Winn LM, Afrooz ARMN, Saleh NB, Walker VK (2011) The effect of $\mathrm{TiO}_{2}$ and Ag nanoparticles on reproduction and development of Drosophila melanogaster and CD-1 mice. Toxicol Appl Pharmacol 257(3):429436

93. Pialoux V, Mounier R, Brown AD, Steinback CD, Rawling JM, Poulin MJ (2009) Relationship between oxidative stress and HIF-1 a mRNA during sustained hypoxia in humans. Free Radic Biol Med 46(2):321-326

94. Rajapakse K, Drobne D, Valant J, Vodovnik M, Levart A, Marinsek-Logar R (2012) Acclimation of tetrahymena thermophila to bulk and nano- $\mathrm{TiO}_{2}$ particles by changes in membrane fatty acids saturation. $\mathrm{J}$ Hazard Mater 221:199-205

95. Rao KG, Ashok CH, Venkateswara Rao K, Shilpa Chakra CH, Rajendar V (2015) Synthesis of $\mathrm{TiO}_{2}$ nanoparticles from orange fruit waste Int. J. Multidiscip. Adv Res Trends II(I): 82-90

96. Reeves JF, Davies SJ, Dodd NJF, Jha AN (2008) Hydroxyl radicals (OH) are associated with titanium dioxide $\left(\mathrm{TiO}_{2}\right)$ nanoparticle-induced cytotoxicity and oxidative DNA damage in fish cells. Mutat Res Fundam Mol Mech Mutagen 640:113-122

Page $17 / 28$ 
97. Reiner Ž (2017) Hypertriglyceridaemia and risk of coronary artery disease. Nat Rev Cardiol 14(7):401-411

98. Rikans LE, Hornbrook KR (1997) Lipid peroxidation, antioxidant protection and aging. Biochim Biophys Acta Mol Basis Dis 1362:116-127

99. Roger B, Lagarce F, Garcion E, Benoit JP (2010) Biopharmaceutical parameters to consider in order altering the fate of nanocarriers after oral delivery. Nanomed 5(2):287-306

100. Rossi EM, Pylkkänen L, Koivisto AJ, Vippola M, Jensen KA, Miettinen M, Sirola K, Nykäsenoja H, Karisola P, Stjernvall T, Vanhala E, Kiilunen M, Pasanen P, Mäkinen M, Hämeri K, Joutsensaari J, Tuomi T, Jokiniemi J, Wolff $\mathrm{H}$, Savolainen K, Matikainen S, Alenius $\mathrm{H}$ (2010) Airway exposure to silica-coated $\mathrm{TiO}_{2}$ nanoparticles induces pulmonary neutrophilia in mice. Toxicol Sci 113:422-433

101. Ruberto G, Baratta MT (2000) Antioxidant activity of selected essential oil components in two lipid model systems. Food Chem 69(2):167-174

102. Sadat SM, Jahan ST, Haddadi A (2016) Effects of size and surface charge of polymeric nanoparticles on in vitro and in vivo applications. J Biomater Nanobiotechnol 7:91-108

103. Sanders K, Degn LL, Mundy WR, Zucker RM, Dreher K, Zhao B, Roberts JE, Boyes WK (2012) In vitro phototoxicity and hazard identification of nano-scale titanium dioxide. Toxicol Appl Pharmacol 258(2):226-236

104. Saquib Q, Al-Khedhairy AA, Siddiqui MA, Abou-Tarboush FM, Azam A, Musarrat J (2012) Titanium dioxide nanoparticles induced cytotoxicity, oxidative stress and DNA damage in human amnion epithelial (WISH) cells. Toxicol In Vitro 26:351-361. doi:10.1016/j.tiv.2011. 12.011

105. Sharma P, Singh R, Jan M (2014) Dose-dependent effect of deltamethrin in testis, liver, and kidney of Wistar rats. Toxicol Int 21(2):131-139

106. Shi Z, Niu Y, Wang Q, Shi L, Guo H, Liu Y, Zhu Y, Liu S, Liu C, Chen X (2015) Reduction of DNA damage induced by titanium dioxide nanoparticles through Nrf2 in vitro and in vivo. J Hazard Mater 298:310-319

107. Shukla RK, Kumar A, Vallabani NVS, Pandey AK, Dhawan A (2014) Titanium dioxide nanoparticle-induced oxidative stress triggers DNA damage and hepatic injury in mice. Nanomed 9:1423-1434

108. Swathi N, Dayalan S, Shanmugam R, Lakshmi T (2019) Green synthesis of titanium dioxide nanoparticles using Cassia fistula and its antibacterial activity. Int J Res Pharm Sci 10(2):856-860

109. Sycheva LP, Zhurkov VS, lurchenko VV, Daugel-Dauge NO, Kovalenko MA, Krivtsova EK, Durnev AD (2011) Investigation of genotoxic and cytotoxic effects of micro and nanosized titanium dioxide in six organs of mice in vivo. Mutat Res Genet Toxicol Environ Mutagen 726(1):8-14

110. Tao F, Hill LE, Peng Y, Gomes GL (2014) Synthesis and characterization of $\beta$-cyclodextrin inclusion complexes of thymol and thyme oil for antimicrobial delivery applications. LWT- Food Sci Technol 59:247-255

111. Thakur BK, Kumar A, Kumar D (2019) Green synthesis of titanium dioxide nanoparticles using Azadirachta indica leaf extract and evaluation of their antibacterial activity. S Afr J Bot 124:223-227

112. Thapa BR, Walia A (2007) Liver function tests and their interpretation. Ind J Pediatr 74(7):663-671

113. Torrado AM, Cortés A, Salgado JM, Max B, Rodríguez N, Bibbins BP, Converti A, Domínguez JM (2011) Citric acid production from orange peel wastes by solid-state fermentation. Braz J Microbiol 42:394-409

114. Trouiller B, Reliene R, Westbrook A, Solaimani P, Schiestl RH (2009) Titanium dioxide nanoparticles induce DNA damage and genetic instability in vivo in mice. Cancer Res 69(22):8784-8789

115. Tucci P, Porta G, Agostini M, Dinsdale D, lavicoli I, Cain K, Finazzi-Agró A, Melino G, Willis A (2013) Metabolic effects of $\mathrm{TiO}_{2}$ nanoparticles, a common component of sunscreens and cosmetics, on human keratinocytes. Cell Death Dis 4:e549. doi:10.1038/cddis

Page $18 / 28$ 
116. Valentini X, Rugira P, Frau A, Tagliatti V, Conotte R, Laurent S, Colet JM, Nonclercq D (2019) Hepatic and renal toxicity induced by $\mathrm{TiO}_{2}$ nanoparticles in rats: A morphological and metabonomic study. J Toxicol Article ID 5767012:19 pages

117. Wang J, Zhou G, Chen C, Yu H, Wang T, Ma Y, Jia G, Gao Y, Li B, Sun J, Li Y, Jiao F, Zhao Y, Chai Z (2007) Acute toxicity and biodistribution of different sized titanium dioxide particles in mice after oral administration. Toxicol Lett 168(2):176-185

118. Wang X, Yu S, Jin J, Wang H, Alharbi NS, Alsaedi A, Hayat T, Wang X (2016) Application of graphene oxides and graphene oxide-based nanomaterials in radionuclide removal from aqueous solutions. Sci Bull 61(20):583-1593

119. Wang Y, Cui H, Zhou J, Li F (2014) Cytotoxicity, DNA damage and apoptosis induced by titanium dioxide nanoparticles in human nonsmall cell lung cancer A549 cells. Environ Sci Pollut Res 22:5519-5530. doi:10.1007/s11356-014-3717-7

120. Weir A, Westerhoff P, Fabricius L, von Goetz N (2012) Titanium dioxide nanoparticles in food and personal care products. Environ Sci Technol 46(4):2242-2250

121. Woranuch S, Yoksan R (2013) Eugenol-loaded chitosan nanoparticles. I. thermal stability improvement of eugenol through encapsulation. J Carbohydr Polym 96:578-585

122. Wu T, Tang M (20180 The inflammatory response to silver and titanium dioxide nanoparticles in the central nervous system. Nanomed (Lond) 13(2): 233-249

123. Xu YY, Howes T, Adhikari B, Bhandari B (2013) Effects of emulsification of fat on the surface tension of protein solutions and surface properties of the resultant spray-dried particles. Drying Technol 31(16):1939-1950

124. Youdim KA, Deans SG, Finlayson HJ (2002) The antioxidant properties of thyme (Thymus zygis L.) essential oil: an inhibitor of lipid peroxidation and a free radical scavenger. J Essent Oil Res 14(3):210-215

125. Zhao J, BowmanL,ZhangX,VallyathanV,YoungSH,CastranovaV,DingM(2009)Titanium dioxide (TiO2) nanoparticles induce JB6 Cell apoptosis through activation of the caspase-8/Bid and mitochondrial pathways. J Toxicol Environ Health A 72(19): 1141-1149.

126. Zhao Y, Howe JLC, Yu Z, Leong DT, Chu JJH, Loo JSC, Ng KW (2013) Exposure to titanium dioxide nanoparticles induces autophagy in primary human keratinocytes. Small 9: 387-392. doi: 10.1002/smll.2012 01363

\section{Tables}

Table 1. Details giving primer sequences for the genes amplified 


\begin{tabular}{|c|c|c|c|c|}
\hline cDNA & $\begin{array}{l}\text { Accession } \\
\text { number }\end{array}$ & Forward primer & Reverse primer & $\begin{array}{l}\text { RT-PCR } \\
\text { product } \\
\text { size }\end{array}$ \\
\hline GAPDH & NM_017008.4 & CAAGGTCATCCATGACAACTTTG & GTCCACCACCCTGTTGCTGTAG & 496 \\
\hline $\begin{array}{l}\text { Cu-Zn } \\
\text { SOD }\end{array}$ & FQ210282.1 & GCAGAAGGCAAGCGGTGAAC & TAGCAGGACAGCAGATGAGT & 477 \\
\hline GPx & NM_030826.4 & CTCTCCGCGGTGGCACAGT & CCACCACCGGGTCGGACATAC & 290 \\
\hline CAT & NM_012520.2 & GCGAATGGAGAGGCAGTGTAC & GAGTGACGTTGTCTTCATTAGCACTG & 652 \\
\hline Bax & NM_017059.2 & AGGATGATTGCTGATGTGGATAC & CACAAAGATGGTCACTGTCTGC & 300 \\
\hline $\mathrm{Bcl}-2$ & NM_016993.2 & GCTACGAGTGGGATACTGGAGA & AGTCATCCACAGAGCGATGTT & 446 \\
\hline TNF-a & NM_012675.3 & CCACCACGCTCTTCTGTCTAC & ACCACCAGTTGGTTGTCTTTG & 256 \\
\hline
\end{tabular}

Table 2. Chemical constitutes of ETEO identified by GC-MS 


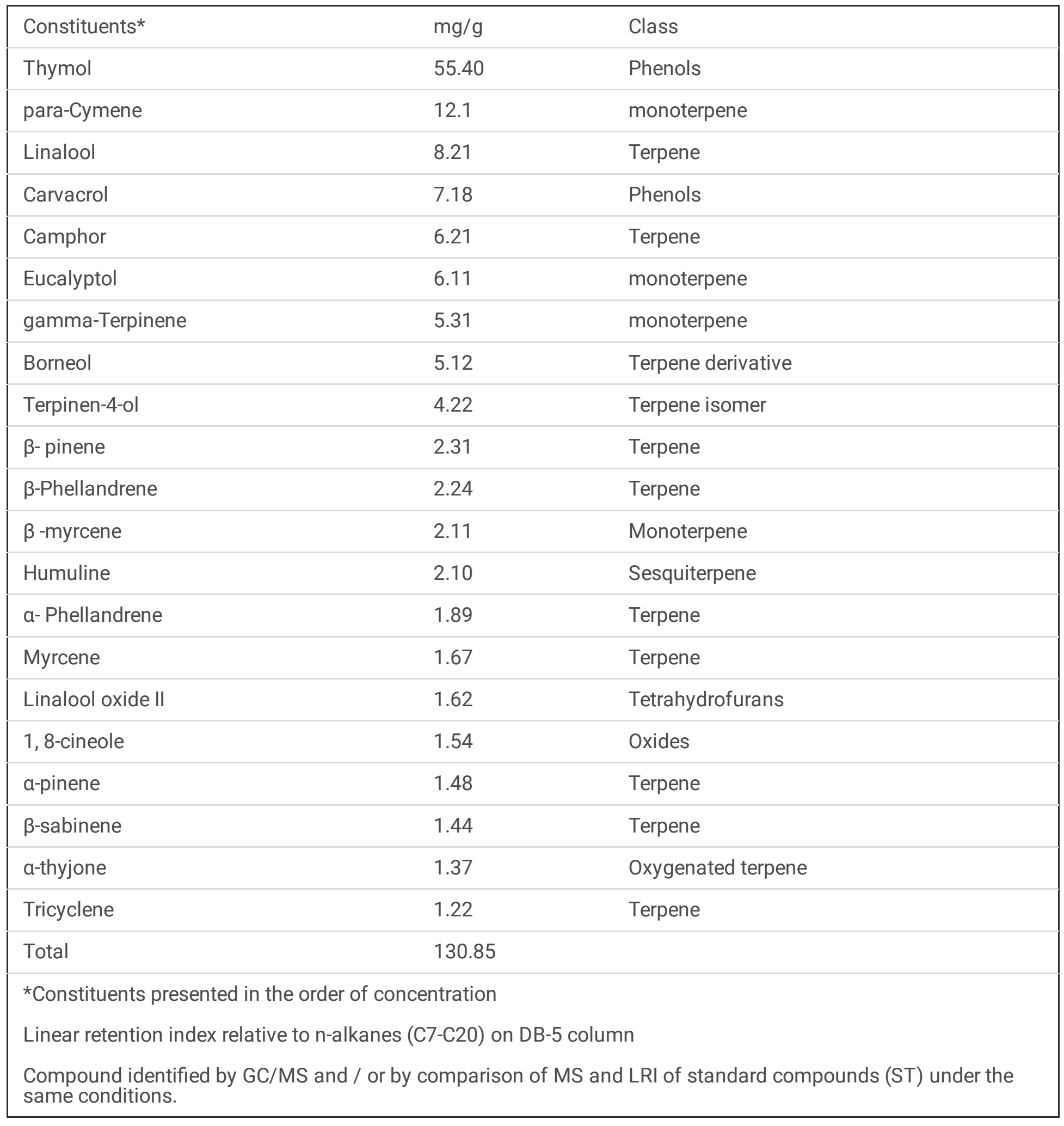

Table 3. Effect of ETEO on serum biochemical parameters in rats treated with $\mathrm{TiO}_{2}-\mathrm{NPs}$ 


\begin{tabular}{|c|c|c|c|c|c|c|}
\hline $\begin{array}{l}\text { Groups } \\
\text { Parameter }\end{array}$ & Control & $\mathrm{TiO}_{2}-\mathrm{NPs}$ & $\begin{array}{l}\text { ETEO } \\
\text { (LD) }\end{array}$ & $\begin{array}{l}\text { ETEO } \\
(\mathrm{HD})\end{array}$ & $\begin{array}{l}\mathrm{TiO}_{2}-\mathrm{NPS}+ \\
\text { ETEO (LD) }\end{array}$ & $\begin{array}{l}\mathrm{TiO}_{2}-\mathrm{NPS}+ \\
\text { ETEO (HD) }\end{array}$ \\
\hline $\operatorname{ALT}(\mathrm{U} / \mathrm{L})$ & $\begin{array}{l}41.33 \pm \\
1.86^{a}\end{array}$ & $\begin{array}{l}79.00 \pm \\
4.16^{b}\end{array}$ & $\begin{array}{l}37.33 \pm \\
2.60^{c}\end{array}$ & $\begin{array}{l}37.33 \pm \\
2.33^{c}\end{array}$ & $\begin{array}{l}66.33 \pm \\
1.45^{d}\end{array}$ & $\begin{array}{l}52.00 \pm \\
2.00^{d}\end{array}$ \\
\hline AST (U/L) & $\begin{array}{l}144.75 \pm \\
5.81^{a}\end{array}$ & $\begin{array}{l}209.00 \pm \\
2.97^{b}\end{array}$ & $\begin{array}{l}131.75 \pm \\
5.60^{c}\end{array}$ & $\begin{array}{l}135.75 \pm \\
6.13^{c}\end{array}$ & $\begin{array}{l}175.75 \pm \\
6.17^{d}\end{array}$ & $\begin{array}{l}150.00 \pm \\
4.53^{a}\end{array}$ \\
\hline Alb (mg/dl) & $2.74 \pm 0.11^{a}$ & $1.77 \pm 0.05^{\mathrm{b}}$ & $2.59 \pm 0.02^{c}$ & $2.72 \pm 0.06^{a}$ & $2.80 \pm 0.11^{a}$ & $2.94 \pm 0.11^{a}$ \\
\hline TP (g/dl) & $6.48 \pm 0.21^{\mathrm{a}}$ & $5.47 \pm 0.23^{b}$ & $6.27 \pm 0.35^{a}$ & $6.85 \pm 0.29^{a}$ & $6.41 \pm 0.17^{a}$ & $6.88 \pm 0.21^{a}$ \\
\hline T.BIL (mg/dl) & $0.09 \pm 0.01^{a}$ & $0.12 \pm 0.01^{\mathrm{b}}$ & $0.09 \pm 0.01^{a}$ & $0.08 \pm 0.01^{a}$ & $0.08 \pm 0.01^{a}$ & $0.08 \pm 0.01^{a}$ \\
\hline D.BIL (mg/dl) & $0.03 \pm 0.01^{a}$ & $0.16 \pm 0.01^{b}$ & $0.03 \pm 0.01^{a}$ & $0.03 \pm 0.01^{\mathrm{a}}$ & $0.06 \pm 0.03^{c}$ & $0.03 \pm 0.01^{a}$ \\
\hline $\begin{array}{l}\text { Cratinine } \\
(\mathrm{mg} / \mathrm{dl})\end{array}$ & $0.81 \pm 0.06^{a}$ & $1.65 \pm 0.05^{\mathrm{b}}$ & $0.72 \pm 0.04^{c}$ & $0.63 \pm 0.03^{d}$ & $0.97 \pm 0.01^{e}$ & $0.83 \pm 0.02^{a}$ \\
\hline Urea (mg/dl) & $\begin{array}{l}49.67 \pm \\
4.48^{a}\end{array}$ & $\begin{array}{l}73.67 \pm \\
2.73^{b}\end{array}$ & $\begin{array}{l}47.00 \pm \\
2.65^{\mathrm{a}}\end{array}$ & $\begin{array}{l}45.33 \pm \\
3.76^{a}\end{array}$ & $\begin{array}{l}59.00 \pm \\
5.03^{c}\end{array}$ & $\begin{array}{l}45.33 \pm \\
2.03^{a}\end{array}$ \\
\hline $\begin{array}{l}\text { Uric acid } \\
(\mathrm{mg} / \mathrm{dl})\end{array}$ & $1.26 \pm 0.17^{\mathrm{a}}$ & $2.20 \pm 0.10^{b}$ & $1.22 \pm 0.14^{\mathrm{a}}$ & $1.54 \pm 0.13^{c}$ & $1.76 \pm 0.08^{d}$ & $1.39 \pm 0.19^{e}$ \\
\hline
\end{tabular}

Table 4. Effect of ETEO extract on serum lipid profile parameters in rats treated with $\mathrm{TiO}_{2}-\mathrm{NPs}$

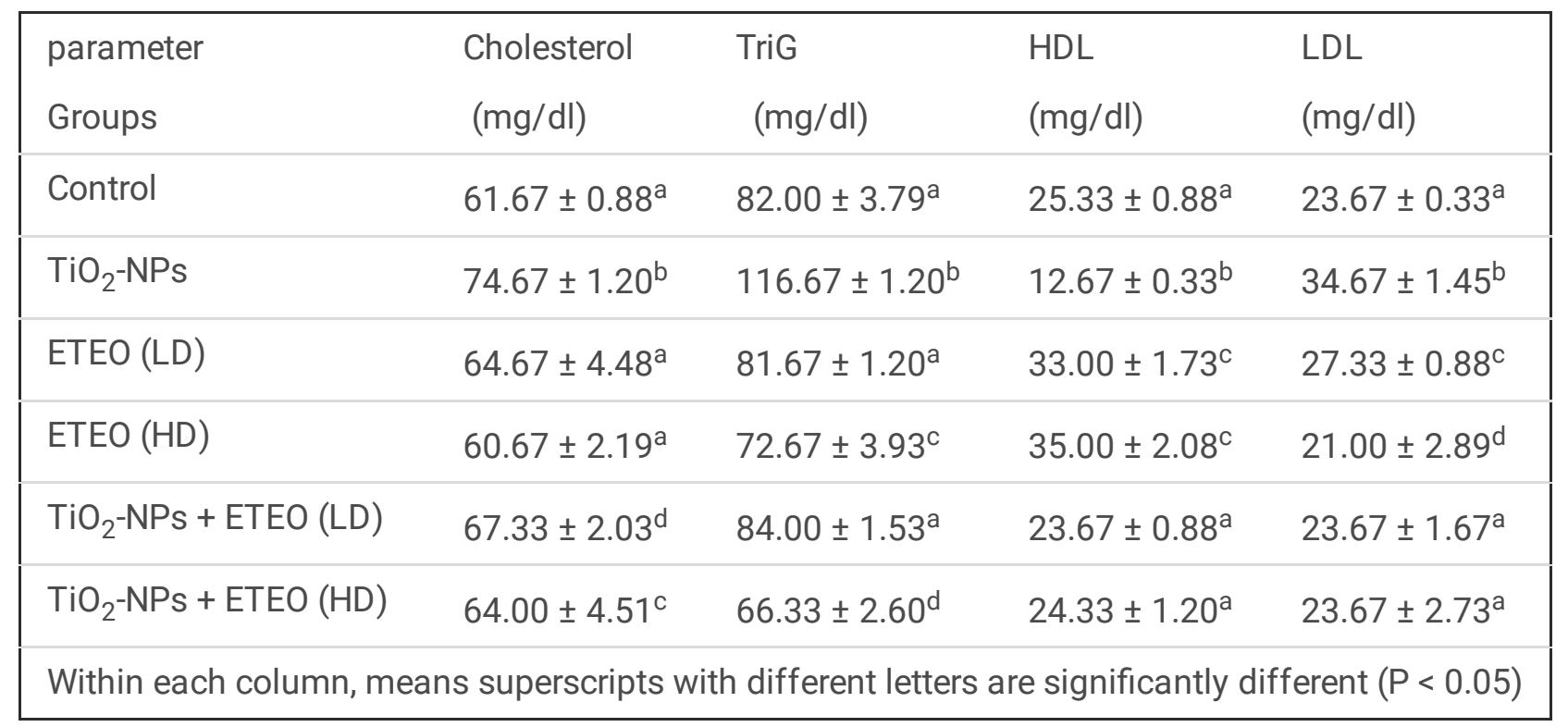

Table 5. Effects of ETEO extract on NO and MDA in the liver and kidney tissues of rats treated with $\mathrm{TiO}_{2}-\mathrm{NPs}$ 


\begin{tabular}{|c|c|c|c|c|}
\hline \multirow{3}{*}{$\begin{array}{l}\text { Parameter } \\
\text { Groups }\end{array}$} & \multirow{2}{*}{\multicolumn{2}{|c|}{$\begin{array}{l}\text { NO } \\
(\mu \mathrm{M} / \mathrm{mg})\end{array}$}} & \multirow{2}{*}{\multicolumn{2}{|c|}{$\begin{array}{l}\text { MDA } \\
(\mathrm{nmol} / \mathrm{g})\end{array}$}} \\
\hline & & & & \\
\hline & Liver & Kidney & Liver & Kidney \\
\hline Control & $553.33 \pm 3.80^{a}$ & $850.33 \pm 5.67^{a}$ & $130.98 \pm 4.97^{a}$ & $244.32 \pm 4.46^{a}$ \\
\hline $\mathrm{TiO}_{2}-\mathrm{NPs}$ & $947.67 \pm 9.94^{b}$ & $1104.00 \pm 9.22^{b}$ & $233.76 \pm 3.70^{b}$ & $353.42 \pm 6.45^{b}$ \\
\hline ETEO (LD) & $520.00 \pm 5.28^{c}$ & $830.00 \pm 5.51^{c}$ & $109.26 \pm 5.26^{c}$ & $237.10 \pm 3.77^{c}$ \\
\hline ETEO (HD) & $510.67 \pm 4.67^{d}$ & $768.00 \pm 8.01^{d}$ & $101.71 \pm 2.51^{d}$ & $227.69 \pm 4.76^{d}$ \\
\hline $\mathrm{TiO}_{2}-\mathrm{NPs}+\mathrm{ETEO}(\mathrm{LD})$ & $643.33 \pm 5.96^{e}$ & $909.33 \pm 5.07^{e}$ & $130.99 \pm 3.26^{a}$ & $269.66 \pm 5.29^{c}$ \\
\hline $\mathrm{TiO}_{2}-\mathrm{NPs}+\mathrm{ETEO}(\mathrm{HD})$ & $620.00 \pm 2.82^{f}$ & $806.67 \pm 3.33^{f}$ & $129.54 \pm 4.46^{a}$ & $253.21 \pm 8.14^{d}$ \\
\hline
\end{tabular}

Table 6. Effect of ETEO on antioxidant enzyme activity in liver and kidney tissue of rats treated with $\mathrm{TiO}_{2}-\mathrm{NPs}$

\begin{tabular}{|c|c|c|c|c|c|c|}
\hline \multirow{2}{*}{$\begin{array}{l}\text { Parameter } \\
\text { Groups }\end{array}$} & \multicolumn{2}{|c|}{$\begin{array}{l}\text { CAT } \\
\text { (mU/g tissue) }\end{array}$} & \multicolumn{2}{|c|}{$\begin{array}{l}\text { GPX } \\
\text { (U/mg tissue) }\end{array}$} & \multicolumn{2}{|c|}{$\begin{array}{l}\text { SOD } \\
\text { (U/mg tissue) }\end{array}$} \\
\hline & Liver & Kidney & Liver & Kidney & Liver & Kidney \\
\hline Control & $\begin{array}{l}6.43 \pm \\
0.27^{a}\end{array}$ & $\begin{array}{l}8.82 \pm \\
0.05^{\mathrm{a}}\end{array}$ & $\begin{array}{l}32.55 \pm \\
2.07^{a}\end{array}$ & $\begin{array}{l}24.64 \pm \\
0.59^{a}\end{array}$ & $\begin{array}{l}2.24 \pm \\
0.14^{\mathrm{a}}\end{array}$ & $\begin{array}{l}2.80 \pm \\
0.03^{a}\end{array}$ \\
\hline $\mathrm{TiO}_{2}$-NPs & $\begin{array}{l}2.19 \pm \\
0.11^{b}\end{array}$ & $\begin{array}{l}3.75 \pm \\
0.03^{b}\end{array}$ & $\begin{array}{l}20.97 \pm \\
3.75^{b}\end{array}$ & $\begin{array}{l}10.50 \pm \\
0.32^{b}\end{array}$ & $\begin{array}{l}1.24 \pm \\
0.14^{b}\end{array}$ & $\begin{array}{l}1.67 \pm \\
0.06^{\mathrm{b}}\end{array}$ \\
\hline ETEO (LD) & $6.76 \pm 0.19^{a}$ & $\begin{array}{l}8.20 \pm \\
0.61^{a}\end{array}$ & $\begin{array}{l}35.37 \pm \\
1.82^{\mathrm{a}}\end{array}$ & $\begin{array}{l}27.91 \pm \\
0.32^{c}\end{array}$ & $\begin{array}{l}2.74 \pm \\
0.14^{\mathrm{C}}\end{array}$ & $\begin{array}{l}2.86 \pm \\
0.14^{\mathrm{a}}\end{array}$ \\
\hline ETEO (HD) & $6.77 \pm 0.45^{a}$ & $\begin{array}{l}8.58 \pm \\
0.26^{a}\end{array}$ & $\begin{array}{l}33.28 \pm \\
0.54^{a}\end{array}$ & $\begin{array}{l}32.00 \pm \\
0.43^{d}\end{array}$ & $\begin{array}{l}3.15 \pm \\
0.19^{d}\end{array}$ & $\begin{array}{l}2.88 \pm \\
0.01^{a}\end{array}$ \\
\hline $\begin{array}{l}\mathrm{TiO}_{2}-\mathrm{NPs}+\mathrm{ETEO} \\
(\mathrm{LD})\end{array}$ & $4.19 \pm 0.81^{d}$ & $\begin{array}{l}6.28 \pm \\
0.75^{c}\end{array}$ & $\begin{array}{l}33.38 \pm \\
3.23^{a}\end{array}$ & $\begin{array}{l}16.95 \pm \\
0.98^{\mathrm{e}}\end{array}$ & $\begin{array}{l}1.49 \pm \\
0.04^{\mathrm{e}}\end{array}$ & $\begin{array}{l}1.98 \pm \\
0.02^{c}\end{array}$ \\
\hline $\begin{array}{l}\mathrm{TiO}_{2}-\mathrm{NPs}+\mathrm{ETEO} \\
(\mathrm{HD})\end{array}$ & $4.73 \pm 0.56^{d}$ & $\begin{array}{l}6.45 \pm \\
0.70^{c}\end{array}$ & $\begin{array}{l}30.11 \pm \\
0.14^{\mathrm{a}}\end{array}$ & $\begin{array}{l}19.95 \pm \\
0.98^{f}\end{array}$ & $\begin{array}{l}1.81 \pm \\
0.08^{f}\end{array}$ & $\begin{array}{l}2.48 \pm \\
0.02^{d}\end{array}$ \\
\hline
\end{tabular}

Table 7. Effects of ETEO on serum cytokines in rats treated with $\mathrm{TiO}_{2}-\mathrm{NPs}$ 


\begin{tabular}{|llll|}
\hline $\begin{array}{l}\text { parameter } \\
\text { Groups }\end{array}$ & $\begin{array}{l}\text { AFP } \\
(\mathrm{ng} / \mathrm{ml})\end{array}$ & $\begin{array}{l}\text { TNF-a } \\
(\mathrm{ng} / \mathrm{ml})\end{array}$ & $\begin{array}{l}\text { CEA } \\
(\mathrm{ng} / \mathrm{ml})\end{array}$ \\
\hline Control & $0.037 \pm 0.02^{\mathrm{a}}$ & $0.31 \pm 0.03^{\mathrm{a}}$ & $3.22 \pm 0.14^{\mathrm{a}}$ \\
\hline $\mathrm{TiO}_{2}$-NPs & $0.082 \pm 0.01^{\mathrm{b}}$ & $0.58 \pm 0.02^{\mathrm{b}}$ & $4.81 \pm 0.31^{\mathrm{b}}$ \\
\hline ETEO (LD) & $0.035 \pm 0.01^{\mathrm{a}}$ & $0.30 \pm 0.03^{\mathrm{a}}$ & $3.54 \pm 0.13^{\mathrm{c}}$ \\
\hline ETEO (HD) & $0.036 \pm 0.01^{\mathrm{a}}$ & $0.31 \pm 0.01^{\mathrm{a}}$ & $3.44 \pm 0.32^{\mathrm{c}}$ \\
\hline $\mathrm{TiO}_{2}$-NPs + ETEO (LD) & $0.061 \pm 0.014^{\mathrm{c}}$ & $0.32 \pm 0.03^{\mathrm{a}}$ & $3.85 \pm 0.11^{\mathrm{d}}$ \\
\hline $\mathrm{TiO}_{2}$-NPs + ETEO (HD) & $0.053 \pm 0.021^{\mathrm{d}}$ & $0.29 \pm 0.02^{\mathrm{a}}$ & $3.34 \pm 0.14^{\mathrm{c}}$ \\
\hline Within each column, means superscripts with different letters are significantly different $(\mathrm{P}<0.05)$ \\
\hline
\end{tabular}

\section{Figures}
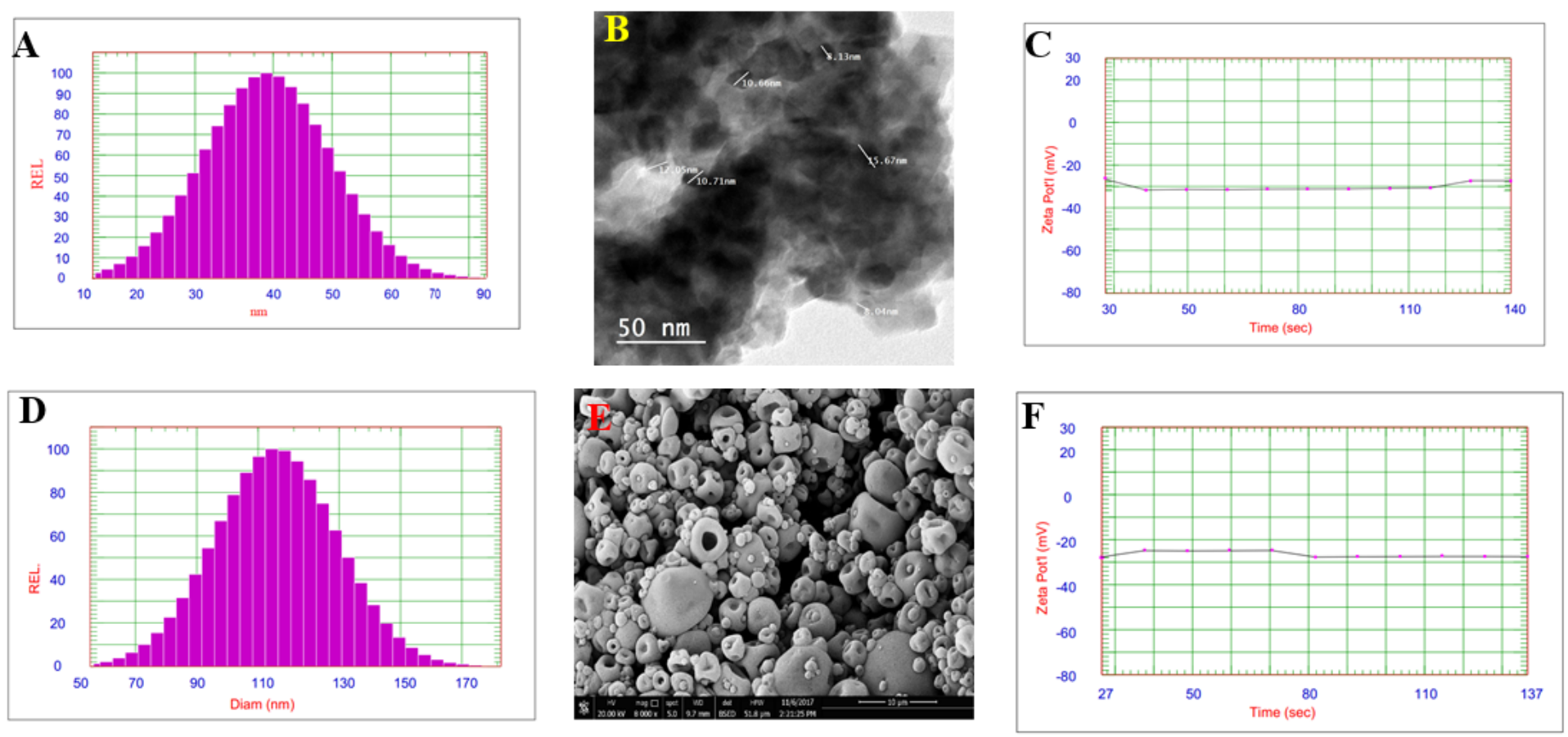

\section{Figure 1}

(A) DLS analysis showing the size distribution of TiO2-NPs, (B) TEM image of TiO2-NPs showing the particle shape and size, (C) ZetaSizer chromatogram showing the zeta potential of TiO2-NPs, (D) DLS analysis showing particles distribution of ETEO, (E) TEM image of ETEO showing the particle shape and size and (F) ZetaSizer chromatogram showing the zeta potential of ETEO. 


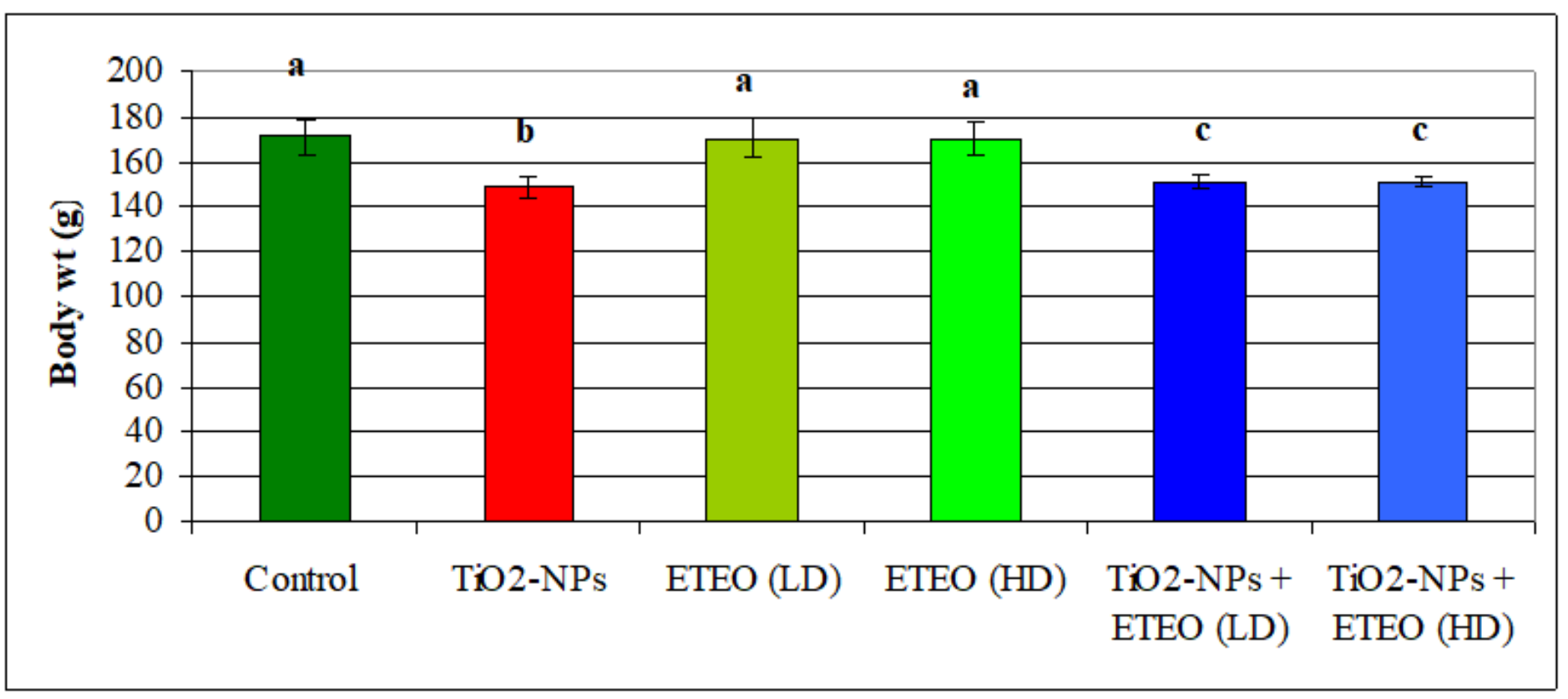

Figure 2

Effect of ETEO on body weight in rats treated with TiO2-NPs
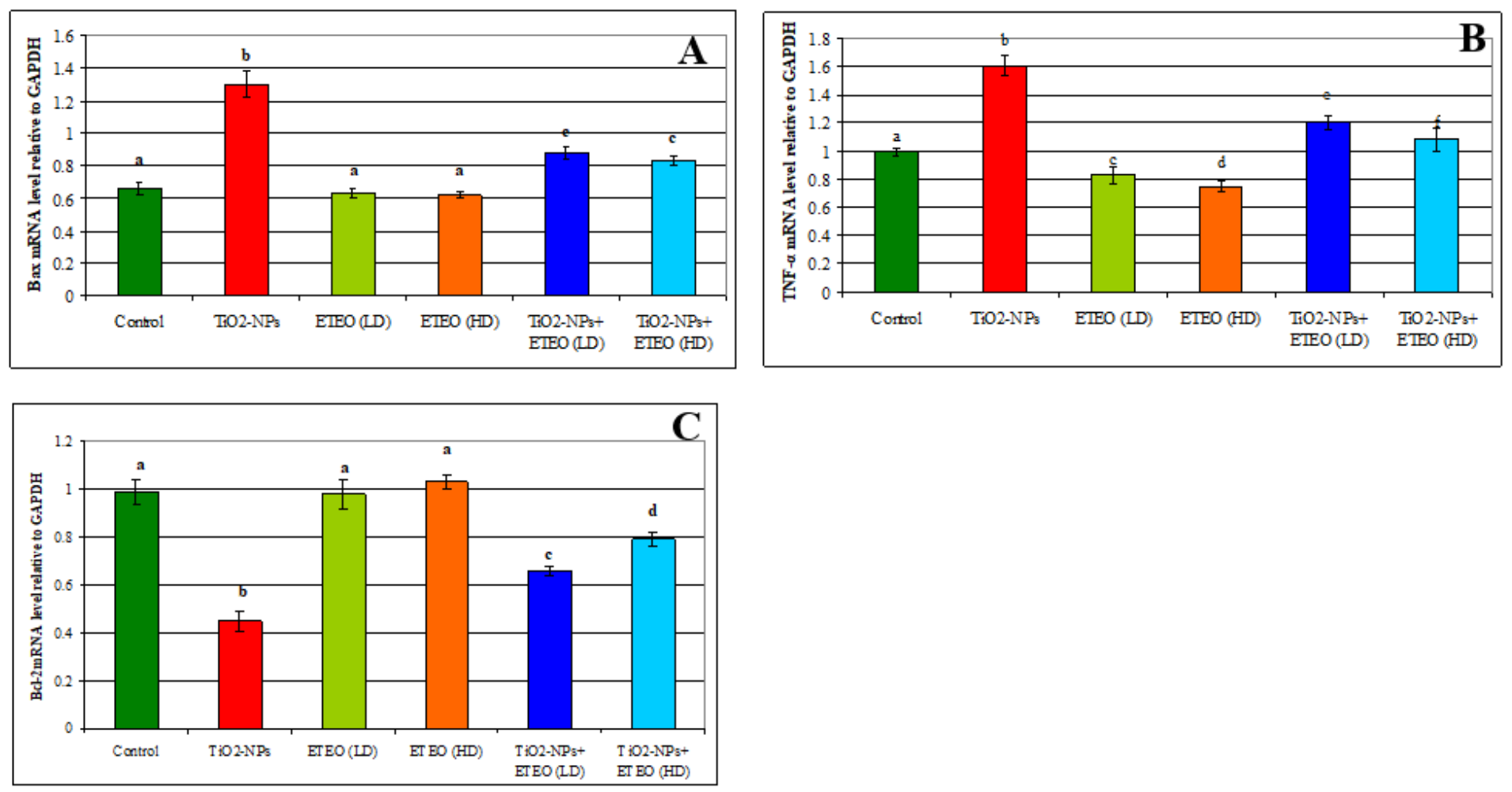

Figure 3

Effect of ETEO on relative expression of $\mathrm{Bax}(\mathrm{A})$, TNF-a (B) and $\mathrm{Bcl}-2$ (C) gene in liver of rats treated with TiO2-NPs. Analyses were performed in triplicate. Data are the mean \pm SE of three different liver samples in same group. Columns superscripts with different letters are significantly difference at $P \leq 0.05$. 

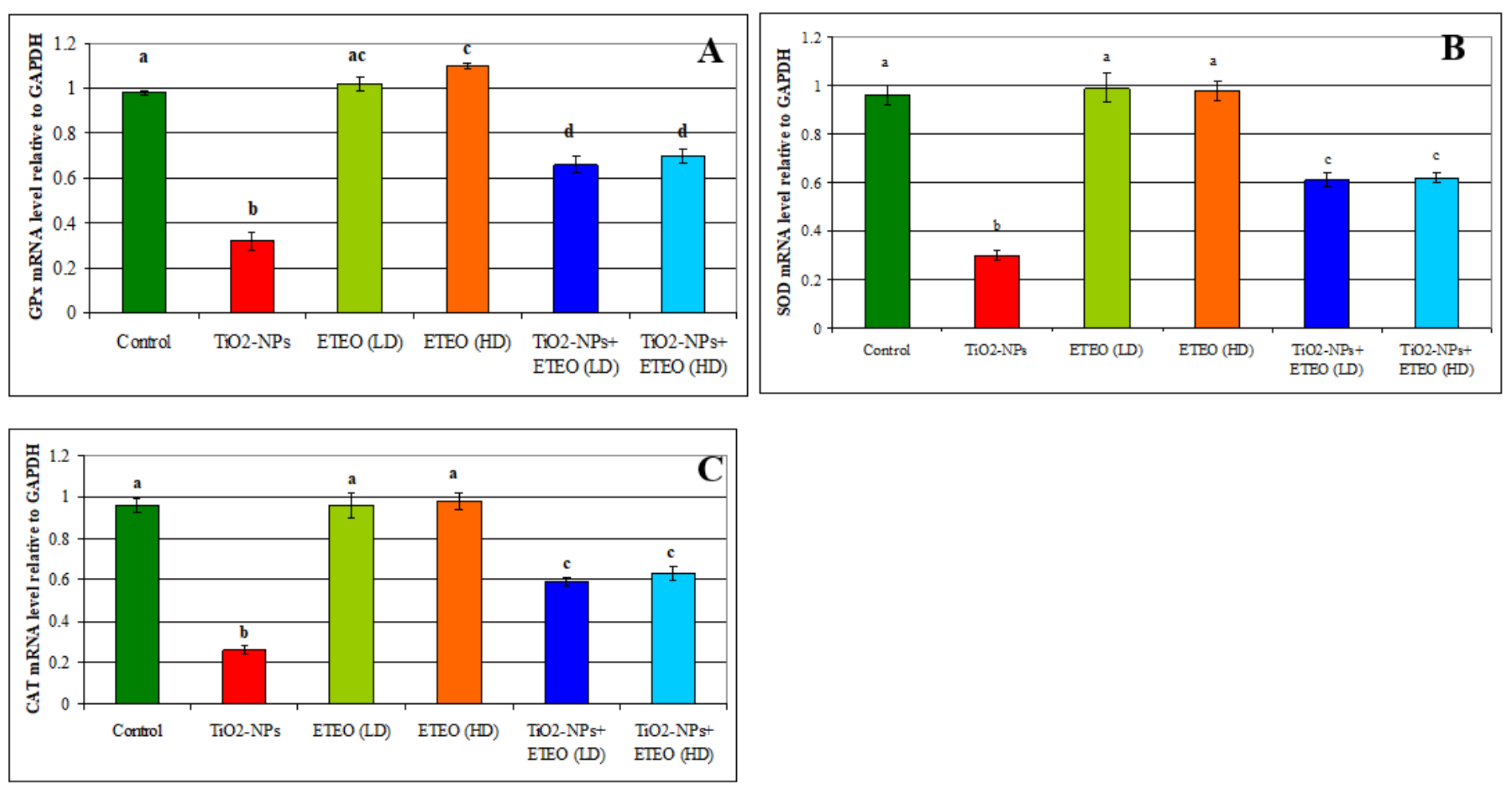

\section{Figure 4}

Effect of ETEO on relative mRNA expression of GPx (A), SOD (B) and CAT (C) gene in liver of rats treated with TiO2NPs. Analyses were performed in triplicate. Data are the mean \pm SE of three different liver samples in same group. Columns superscripts with different letters are significantly different at $P \leq 0.05$.

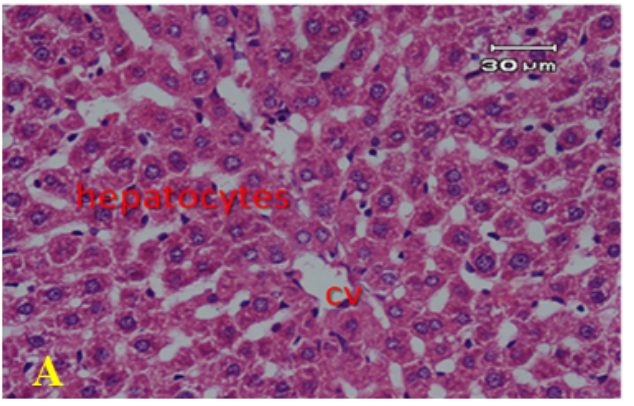

(H\&E X 400)

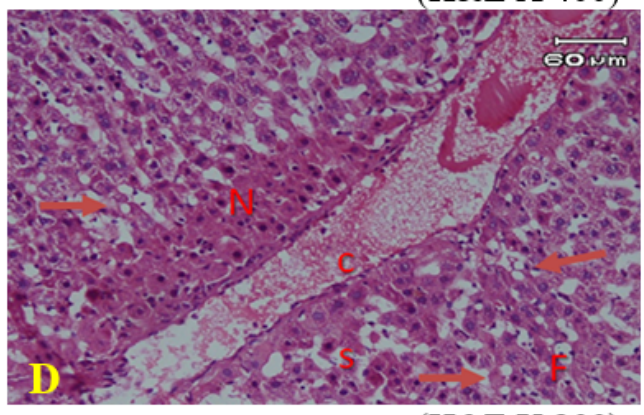

(H\&E X 200)

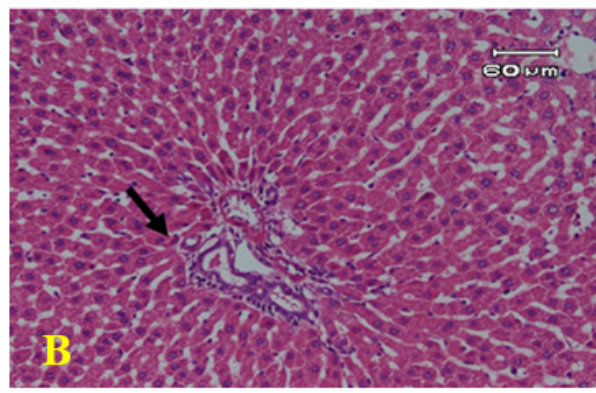

(H\&E X 200)

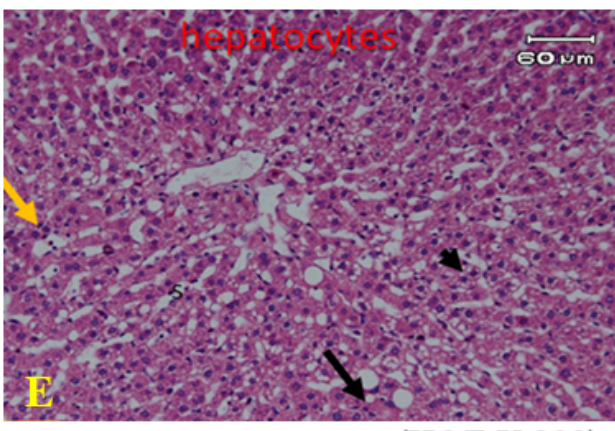

(H\&E X 200)

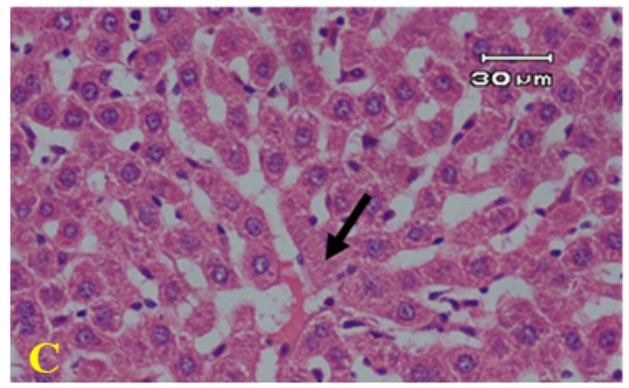

(H\&E X 400)

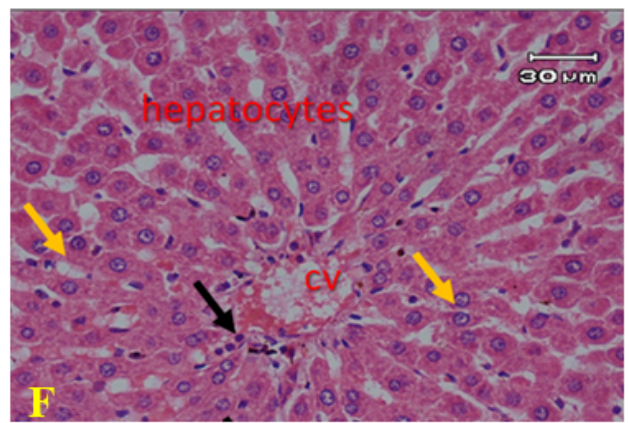

$(\mathrm{H} \& \mathrm{E}$ X400)

Figure 5

Photomicrographs of liver sections of (A) normal control rats showing hepatocytes with normal cytoplasm, vesiculated nuclei and separated by blood sinusoids radiating from the central vein $(\mathrm{CV})$; $(\mathrm{B})$ rat treated with ETEO 
(LD) showing no observable changes in hepatocytes architectuer except few fibrous tissues around the central vein and bile duct hypertrophy; $(\mathrm{C})$ rats treated with ETEO (HD) showing no observable changes in hepatocytes architecture except few fibrous tissues around the central vein and bile duct hypertrophy; (D) rats treated with TiO2NPs showing marked histological alterations in the hepatocytes as disorganization, vacuolar and fatty degeneration (arrow) shrunken hepatocytes with darkly stained pyknotic nuclei $(p)$ patches of necrotic cells around the dilated and congested portal tract also seen $(\mathrm{N})$ and numerous mononuclear cellular infiltration localized in dilated hepatic sinusoids (s); (E) rats treated with TiO2-NPs plus ETEO (LD) showing several histological changes in hepatocytes as vacuolar (arrow head), fatty degeneration (black arrow), pyknotic nuclei (yellow arrow) and increase in mononuclear inflammatory cells; (F) rats treated with TiO2-NPs plus ETEO (HD) showing more improvement in hepatic cells stricter and few inflammatory cells are also seen (black arrow).
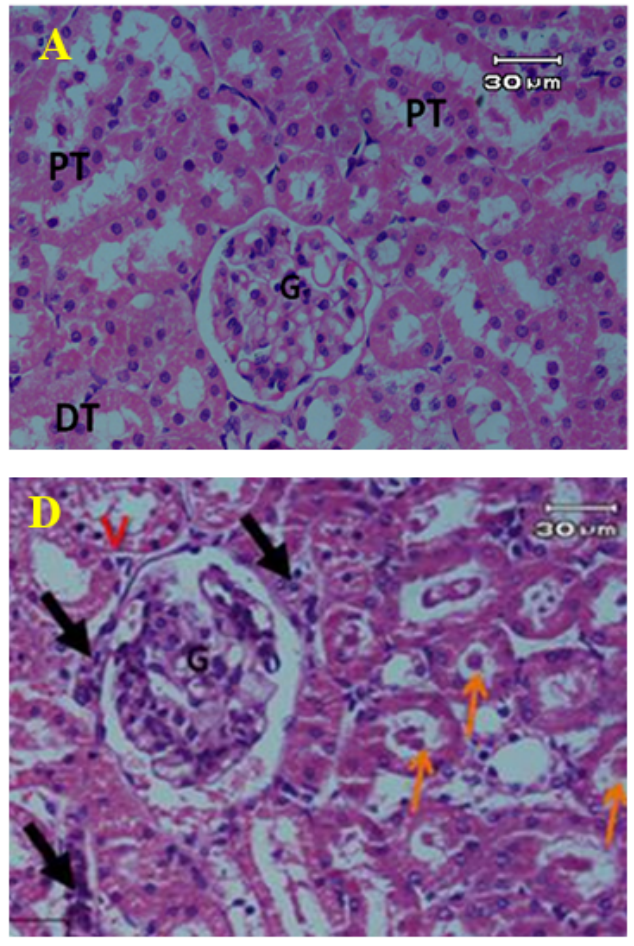
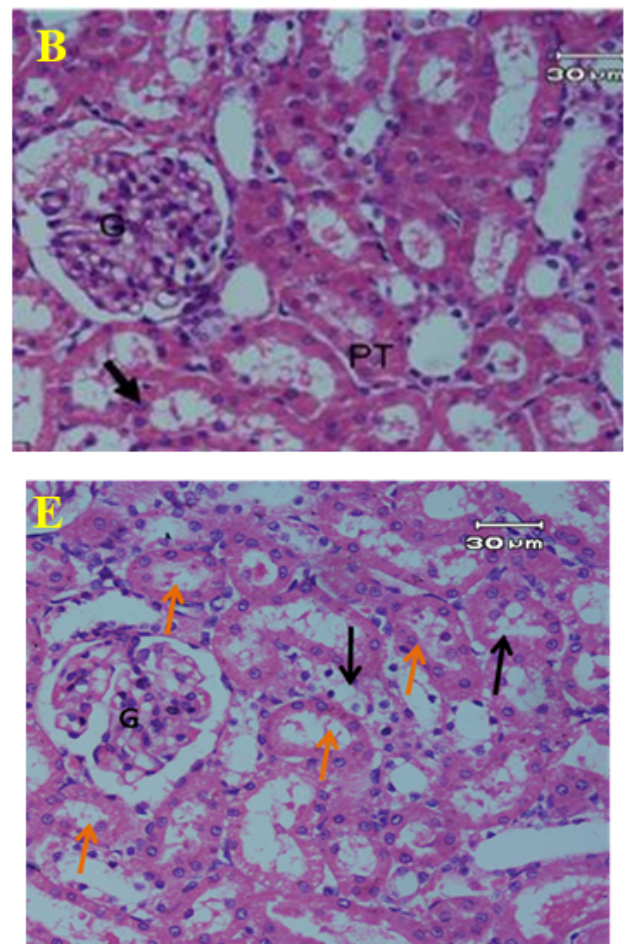
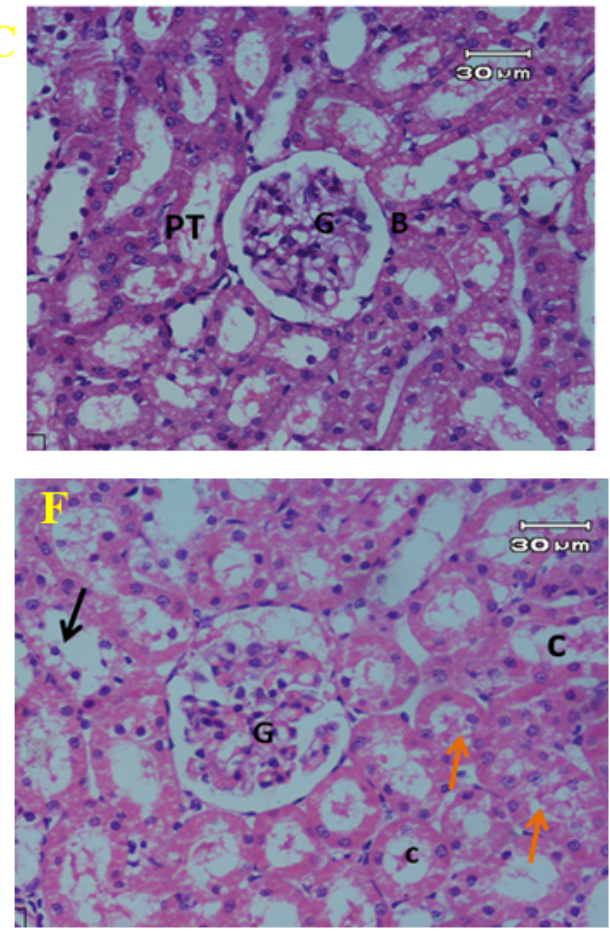

\section{Figure 6}

Photomicrographs of kidney cortex of: (A) control animals showing the proximal convoluted tubules with high cuboidal acidophilic cells and narrow lumen (arrow) and distal convoluted tubules with low cuboidal cells and wide lumen (DT). Note: Renal corpuscle with the parietal layer of Bowman's capsule (BC), glomerulus (G) and the urinally renal space are preserved; (B) Animals treated with ETEO (LD) showing the majority of the tubules (PT) and glomeruli are normal epithelial cells (arrow) except some renal tubules are still with slight hyaline droplet in their lumen and widening of the Bowman's space; (C) animals treated with ETEO (HD) showing tubular lumen dilatation with slight cytoplasmic hyaline (PT), the majority of renal tubules and glomeruli Bowman's capsule (B) are nearly normal; (D) Animal treated with TiO2-NPs showing vacuolar degeneration of the cytoplasm of tubular epithelial cells with deeply stained pyknotic nuclei in some renal tubules $(V)$, some of the lining epithelial cells are exfoliated into the lumen with hyaline droplets (yellow arrow), the renal capsule are shrunken with reduction in glomeruli mesengial cells $(G)$, mononuclear cell infiltrations between degenerated tubule and renal corpuscle (black-arrow); (E) Animals treated with TiO2-NPs plus ETEO (LD) showing few foci of vaculation in tubular epithelial cells (black arrow) or hyaline cytoplasmic droplet in their lumen ( yellow-arrow) .the majority of renal tubules and glomeruli are nearly normal; (F) Animals treated with TiO2-NPs plus ETEO (HD) showing few foci of vaculation in tubular epithelial cells (black arrow) 
or cytoplasmic droplet in their lumen (yellow-arrow), interstitial tubular mononuclear cell infiltrations but the majority of renal tubules and glomeruli are nearly normal. (H \& E X 400). 